IZA DP No. 9413

State and Local Sales Taxes and Business Activity in the United States

Nicholas Saxon

Mehmet Serkan Tosun

Jingjing Yang

October 2015 


\title{
State and Local Sales Taxes and Business Activity in the United States
}

\author{
Nicholas Saxon \\ U.S. Census Bureau \\ Mehmet Serkan Tosun \\ University of Nevada-Reno \\ and IZA \\ Jingjing Yang \\ University of Nevada-Reno
}
Discussion Paper No. 9413
October 2015

\author{
IZA \\ P.O. Box 7240 \\ 53072 Bonn \\ Germany \\ Phone: +49-228-3894-0 \\ Fax: +49-228-3894-180 \\ E-mail: iza@iza.org
}

\begin{abstract}
Any opinions expressed here are those of the author(s) and not those of IZA. Research published in this series may include views on policy, but the institute itself takes no institutional policy positions. The IZA research network is committed to the IZA Guiding Principles of Research Integrity.

The Institute for the Study of Labor (IZA) in Bonn is a local and virtual international research center and a place of communication between science, politics and business. IZA is an independent nonprofit organization supported by Deutsche Post Foundation. The center is associated with the University of Bonn and offers a stimulating research environment through its international network, workshops and conferences, data service, project support, research visits and doctoral program. IZA engages in (i) original and internationally competitive research in all fields of labor economics, (ii) development of policy concepts, and (iii) dissemination of research results and concepts to the interested public.
\end{abstract}

IZA Discussion Papers often represent preliminary work and are circulated to encourage discussion. Citation of such a paper should account for its provisional character. A revised version may be available directly from the author. 


\section{ABSTRACT}

\section{State and Local Sales Taxes and Business Activity in the United States}

There has been an increasing reliance on sales taxation in both the states and counties in the United States. In this paper, we are examining the relationship between state and local sales taxation and business activity in the U.S. by utilizing county-level data for the period 2002-2011. We have found significant negative association between the state and county combined sales tax rate and annual payroll of businesses particularly in the manufacturing sector. There is also evidence of spatial dependence particularly in the payroll response of businesses within the contiguous region. While we found no significant relationship with employment, there is also statistically significant negative association with retail establishments and small establishments with less than 10 employees. It is possible that businesses respond to a sales tax rate increase first, or more directly, by reducing payroll rather than employment. While the economic significance of these results, however, is not found to be overwhelmingly strong, policymakers should still pay attention particularly to how manufacturing businesses respond to sales tax rate tax changes in the form of changes in payroll, and the responses from the small retail establishments.

JEL Classification: H25, H71, H73, J21

Keywords: state and county sales tax, business activity, payroll, employment, number and size of establishments, United States

Corresponding author:

Mehmet Serkan Tosun

Department of Economics

University of Nevada-Reno

Mail Stop 0030

Reno, Nevada 89557

USA

E-mail: tosun@unr.edu 


\section{Introduction}

Sales tax has been one of the most important components of state tax systems. We have seen an increasing reliance on this tax by states over time. More recently, sales tax has also become popular among local governments. Fisher (2007) notes that sales taxes are an important source of revenue for state governments the way that property taxes have always been an important source of revenue for local governments. We also see that local governments are shifting towards sales taxation the way states have done over the years (Fox, 2003). State governments are also increasingly using state sales taxes to redistribute funds to local governments as well, as local governments' role in providing services has also expanded significantly in the last half-century, so we see that the sales tax is also a local policy issue. At the same time there is tendency for the policy discussion to focus more on "business" taxes such as the corporate income tax as those taxes are thought to be more directly related to business activity.

In this paper, we are examining the relationship between state and county combined sales tax rates and the business activity in all counties in the United States during the period 2002-2011. We use spatial regressions to account for the possibility of spatial dependence in business activity among counties. We have found significant negative association between the combined sales tax rate and annual payroll of businesses particularly in the manufacturing sector. Spatial effects, in the form of possible spillovers from business activity in the contiguous region, are also found to be stronger when payroll is used as an indicator of business activity. While we found no significant relationship with employment, there is statistically significant negative association with retail establishments and small establishments with less than 10 employees.

While the economic significance of these results is not overwhelming, the evidence points to potential issues with sales taxation for the policymakers regarding particularly business activity in the manufacturing and retail sectors. While one flag is for annual payroll in manufacturing business, another is for the number of establishments, particularly small establishments, in the retail sector.

In the next section we review the literature, which is followed by a discussion on the data used and the variables. We then present empirical analysis by first providing the empirical specification and summary statistics in a number of tables and figures including maps. We then provide the complete regression results and conclude in the last section of the paper.

\section{Review of Literature}

Some authors have noted the increased use of and interest in the sales $\operatorname{tax}^{1}$, and the recent rise in sales-for-property tax substitution (Krmenec, 1991). Due \& Mikesell (1994) give an exhaustive look into the history of the sales tax, noting that while it was used in response to the revenue issues in the post-depression 1930s, it was essentially a

\footnotetext{
${ }^{1}$ Hageman (2012) provides an exhaustive overview of the literature on sales taxes.
} 
permanent mechanism for seeking revenue by the end of World War II. Wong (1996) has noted that beyond the dislike for property taxes, sales taxes have also increased in use due to increased demand for services, state reluctance to raise taxes, and increases in upperlevel governments creating mandates for lower-level governments. Luna, Bruce, \& Hawkins (2007) point out that the number of local government jurisdictions using a form of sales tax has jumped from around 3,000 in the early 1970s to over 9,000 jurisdictions today.

John F. Due noted early on that the United States contained "the most extensive use of retail sales taxation" (Due, 1957), compared to similar countries. Bartik (1991) introduces some of the issues related to tax competition at a local level in relation to jobs, and the concerns of balancing the positives of job creation and the negatives of creating regressive systems by attracting businesses and the wealthy with tax incentives. This balance was explored by Wasylenko \& McGuire (1985) where they showed that increases in taxes caused discouragement of employment growth in some states. Wassmer \& Anderson (2001) have pointed out the increased use of sales tax development incentives since the 1970s. This increase was partly attributed to the "property tax revolts" that sprung up around the 1970s and 1980s across the country. Government misuse of taxation policies was outlined and discussed in a book about the infamous Proposition 13 in California (O'Sullivan, Sexton, \& Sheffrin, 1995), whereby the public revolted against property tax increases, and the result was not simply political ramifications, but also legal issues and restrictions on government authority over taxation, resulting in governments even more stressed in finding sources of revenue to maintain public satisfaction with provision of services.

Inter-governmental tax competition has become the permanent climate for local governments to operate within, and in some cases local governments are flexing their state arms to receive upper government bonuses in an effort to combat the appeal of a rival government (Duggan, 2012). Fox \& Murray (2004) cover data on business firms and their locational decisions in the 1980s using control and experiment locations to measure the effects within counties and metropolitan statistical areas (MSAs). Their findings showed that these tax competition-based incentives to attract these large firms away from other potential jurisdictions do not significantly positively impact the economic performance of the locations in question, and they call into question the wars over jobs and investment between jurisdictions. Carlton (1983) also finds that there is no significant effect of taxes or state fiscal incentives on these locational decisions of firms.

Jacobs, Ligthart, \& Vrijburg (2010) analyze consumption taxation effects at a state level for the entire nation, finding significant strategic interactions between the 48 contiguous states. Their methodology is more complex in that they attempt to build a model using average effective consumption tax rates instead of the statutory tax rates. While this is a detailed approach it might be problematic since many people, when considering taxation in specific areas, do not consider all the complicated exemptions, potential refunds, and other tax considerations in a given jurisdiction. 
Mikesell \& Zorn (1986) was one of the more prominent studies to discuss that rate increases do not properly address revenue-raising concerns because they erode the tax base. Although, we know that increasing the tax rate is one of the easier responses governments have to increase short-term revenue, the literature is proving that this is an ineffective approach for governments because it merely places further burden upon the same sales tax base. As expected, it also creates some crowding between upper and lower governments over the same tax base, as it is only the total tax rate in a jurisdiction that really matters to consumers and businesses.

Mikesell (2012) recently covered varying cultures and policies of sales taxation at the state level, including inconsistencies in implementation and exemptions, which causes a large concern for government revenue-raising. Covering the large structural changes in fiscal climates over the 1970s and 1980s, Carroll \& Wasylenko (1994) use aggregated state variables to find significant reason to believe that reliance on fiscal policy to stimulate business employment growth could be problematic. They believe that variables of international influence caused local fiscal policies to have less of an impact than they once held by the end of the 1980s.

The literature on lower-level local sales taxes has been focused on cross-border effects. Fox (1986) was a premier study showing that the retail sales tax did actually garner more responsiveness from consumption behavior than other taxes along a state border. Mikesell (1970) was one of the first to empirically analyze the possibility of retail sales decline in a more central city due to an adverse tax differential with border cities. Rohlin, Rosenthal, \& Ross (2012) further this empirical approach by using data on new enterprise locations to find out how businesses decided to locate themselves on borders based on the tax conditions on either side of said border.

This "border effect" is a topic growing in importance as more studies find that proximity to borders and other jurisdictions causes effects on taxation and behavior possibly outside a particular jurisdiction's control. Rogers (2004) recently found that there are many issues outside a government's control with regard to raising revenues from sales taxation. Even if a government is not constrained by a higher government in setting tax rates ${ }^{2}$, it may be limited by border effects that drastically change the behavior of consumers and can affect how well a new sales tax, or a tax rate increase, could possibly raise revenue.

Many studies on local level sales tax effects have also mostly been case studies focused on specific regions or states. McAllister (1961) considered the break-even points of travel costs versus the savings of traveling across a border for lower taxes in order to prove that some border-crossing does occur. Snodgrass \& Otto (1990) use data from Oklahoma and find that this tax differential significantly affects rural communities that might have a relatively higher sales tax rate, but does not necessarily negatively affect

\footnotetext{
${ }^{2}$ The Advisory Commission on Intergovernmental Relations performed a study (Members of Advisory Commission on Intergovernmental Relations, March 1995) discussing the implications of limits on subnational governments and is a good resource, especially considering the taxing limitations placed on these governments.
} 
border communities that can effectively export some of their tax burden to consumers crossing the border to shop there. Walsh \& Jones (1988) show that consumers proximity to a lower tax border and ease of crossing that border were effective incentives for the border effect to occur with shopping, and they also showed this effect was nearly nonexistent with locations distant from any border to another state. Tosun \& Skidmore (2007) show that a decline in food purchases as a result of a tax increase was markedly larger at the border of the state rather than elsewhere.

The use of case-studies ${ }^{3}$ can be an invaluable resource, giving us natural experiments that can be tested. The benefit of these case-study approaches is the ability to "zoom in" on a particular region and really understand the business and shopping effects of sales taxes within the scope of its own personal regional effects. This causes analysis and interpretation to be simpler in that the researcher does not need to worry about the comparative issues between distinctively and structurally different areas of the country, such as comparing New England to California. However, a broader study that uses local level data would give a more complete picture of how sales taxes act overall, rather than merely in a single area.

A recent paper by Agrawal (2014) utilizes the first national panel data for all states across a number of years at a monthly frequency, with the goal of creating a data set for researchers and further research into the differences in Local Option Sales Taxes (LOST) between jurisdictions. Agrawal addresses tax competition issues between states, and finds that state sales tax competition does not only involve the state sales tax, but the total effective sales tax rate, which would include all jurisdictions including LOST and other local sales taxes. This further identifies the need for more analysis involving not only state sales tax data, but further sub-national data on a national scale.

This study uses county level data for the entire United States where both state and county sales tax rates are used in the analysis. This has not been thoroughly done before, and this paper contributes to the literature on the overall impact of sales taxes by using more exhaustive and detailed data.

\section{Data and Variables}

One important aspect of the data work in this paper is to have state and county combined sales tax rates for every county in the U.S. in order to account for discrepancies between local and state sales tax rates. The availability of business activity data ${ }^{4}$ also dictated the use of certain levels of sub-national data, and although doing this at a countylevel for all counties in the entire United States was a difficult task, this allowed for basic business metrics to be tested in order to see if correlations or other associations exist with sales tax rates, and to have a more detailed understanding of sales tax rates at a more micro level as opposed to aggregating at the state level. For simplicity, the only local

\footnotetext{
${ }^{3}$ Zhao \& Hou (Spring 2008) also give an exhaustive case-study into the fiscal issues of sales taxation in Georgia counties.

${ }^{4}$ County Business Patterns by the U.S. Dept. of Commerce, Bureau of the Census, obtainable from http://www.census.gov/econ/cbp/.
} 
sales tax rate (other than state sales tax rates) used was the general county sales tax rate applying to an entire county ${ }^{5}$.

Another issue with empirical work is that many states have demographics that vary widely, and estimating the effects of sales tax rates on businesses using a state measure may not reflect the varying differences across states, for example, the extreme economic, political, and demographic differences between northern and southern California (Almendrala, 2011). An argument could also be made that the increasing importance of the role that local governments play in the provision of public services makes them increasingly more important to study. Counties became a major part of government activities during the twentieth century (NACo, 2013), and a lot of this can be attributed to the recognition that local governments can more closely understand and serve their local conditions and citizens when applying policies, as opposed to blanketed federal policies that may not be able to properly adapt to an insurmountable number of small and unique economies (Brunori, 2007). These increases in local government activity are also concurrent with increases in local government taxing activity.

Taking things down to a county level, we have more clearly defined observations of data, rather than aggregation at the state level. We can allow for analysis of the rising use of county level sales taxes. This allows for some extension of the existing literature, albeit at a simple level, but with a new analysis of how the sales tax rates at the state and county level affect business dynamics, we can begin to provide insight for policy decisions regarding a tax that has not been conclusively and extensively studied at this level.

The variables for the annual payroll in thousands of dollars (Annual Payroll), midmarch employees (Employment), and number of establishments ${ }^{6}$ (Establishments) come from the United States Census Bureau County Business Patterns data set and serve as the dependent variables. These assist in giving an accurate snapshot of business activity in order to help measure the impact of sales tax rates. This dataset is convenient since it is consistent and provided at the county level on an annual basis. A further benefit of this dataset is the ability to pull information based on the North American Industry

\footnotetext{
${ }^{5}$ This means that special rates for food, education, special district, and other taxes not applying to the entire county in a general format were not and could not be used. While the information on other sales tax rates was available from some sources (not all), this would have made data analysis much more of an insurmountable task than it was already approaching. Thus, only the general sales tax rate was used.

Specifically in New Mexico, they do not use a general sales tax at the local level, but instead they use a gross receipts tax that applies in much the same way. Much literature on tax incidence (including textbooks) has already agreed that this tax is going to be pushed forward to the consumer or backwards to employees regardless, and this study is more concerned with how these general taxes on sales affect business dynamics, which means the gross receipts in New Mexico functions much like a local option sales tax. Furthermore, many states used different statutes/names for these taxes, but careful consideration was taken to notice and apply only the single, basic, county-wide sales tax, whether it be called a local option, or a general sales, or other type of tax.

${ }^{6}$ Establishments was used rather than Firms in order to measure the physical "brick and mortar" presence of a company in a county, rather than the existence of a single firm that may have multiple establishments.
} 
Classification System (NAICS). Dependent variables are for total industries (Total Annual Payroll, Total Employment, Total Establishments) ${ }^{7}$, manufacturing (Manufacturing Annual Payroll, Manufacturing Employment, Manufacturing Establishments $)^{8}$, and retail trade (Retail Annual Payroll, Retail Employment, Retail Establishments) ${ }^{9}$. A drawback with the County Business Patterns data set is that counties must report this information, and while it seems very exhaustive, there are chances that the Census Bureau does not receive all required data from some counties. Further, there can be instances of missing data due to withheld information in smaller counties where reporting the business activity would violate the privacy of a single business entity. Finally, there can be some missing information in the study due to counties having zero data to report on certain industries, perhaps because the industry is non-existent in that county or that it may be too small to really capture or report.

The main explanatory variable of interest is the combined state and county sales tax rate $^{10}$ (Combined Rate). While the county sales tax rate alone will be used for some simple statistical analysis, it was not empirically valid as an estimator since the state sales tax rate is generally perceived as larger, and thus the combined state $\&$ county sales tax rate will better give the total sales tax rate picture, as well as provide a nice comparison to the state sales tax rate estimations. The difference between the two estimation types could possibly be attributed to county sales tax rates since that will be the only inherent difference between these two models. Most empirical applications in the literature follow this route of using the total rate in a jurisdiction (if there is a presence of multiple vertical and identical taxes to estimate), and this was also appropriate in this study.

The issues surrounding the county rate are as discussed previously: only a general county-wide sales \& use tax could be used for the study. For simplification, all other types of sales \& use taxes were ignored unless they applied to general sales for an entire county. Further, the county sales tax rates were gathered and compiled by the authors individually and rely upon the resources and accuracy of the various sources in which they were obtained.

Consistent with the literature, many other variables were included to control for other features at the county level that may impact businesses. The hope is that with these

\footnotetext{
${ }^{7}$ Based on total for all NAICS sectors. In the further descriptions of specific sectors (in footnotes), reference will be made to the official definitions of each sector in NAICS 2007, the latest NAICS version within the data set time period.

${ }^{8}$ Based on NAICS Sector \#31 (The data acquired was the existing total of NAICS sectors \#31, \#32, \& \#33). "The Manufacturing sector comprises establishments engaged in the mechanical, physical, or chemical transformation of materials, substances, or components into new products. The assembling of component parts of manufactured products is considered manufacturing, except in cases where the activity is appropriately classified in Sector 23, Construction" (U.S. Dept. of Commerce, Bureau of the Census, 2013).

${ }^{9}$ Based on NAICS Sector \#44 (The data acquired was the existing total of NAICS sectors \#44 \& \#45). "The Retail Trade sector comprises establishments engaged in retailing merchandise, generally without transformation, and rendering services incidental to the sale of merchandise" (U.S. Dept. of Commerce, Bureau of the Census, 2013).

${ }^{10}$ Created by authors' calculations: simply the addition of County Rate + State Rate.
} 
variables, some county effects are being accounted for that may relieve the coefficients on the tax rates to be interpreted as only a function of those tax rates. The top marginal state corporate income tax rate (Corporate) was included, and captures the maximum prevailing income tax rates that corporations face in various states. This variable is included to help capture some of the cost of doing business in a given state. However, this could also be capturing some of the level of business activity in a county as well. At least one paper (Burnes, Neumark, \& White, 2012) discusses the possibility that fiscal zoning, or political involvement in attracting businesses, could impact an economy in such a way that sales tax rates could have a positive association with business activity when comparing to alternate jurisdictions. This is because the use of fiscal zoning is more likely to occur with counties or states that have more business activity interest in the first place, and this can be especially true when distinguishing across industry sectors. As that same paper showed that there can be a trade-off between manufacturing and retail sector jobs when zoning based on taxes. This manufacturing to retail trade-off will be empirically analyzed and discussed at a national scale in this paper. These same theories can apply to the corporate income tax as this tax is also associated with more business activity.

The other control variables included are: the top marginal state individual income tax rate (Individual), which helps observe some of the atmosphere of income within a state; the county personal income in thousands of dollars (Personal), to capture some of the total economic status of the residents of a county; the average annual county labor force (Labor), which shows the portion of the population that is available to be involved in business activity ${ }^{11}$; the annual average unemployment rate (Unemployment), showing some of the economic condition of a county; the percentage of the county population that is age twenty to sixty-four (Working Age), to capture the portion of "working" population in a county; the percentage of the county population that is age sixty-five or older (Senior), which shows the level of senior citizens in a county, or those that are no longer considered working but still likely to have purchasing power; the percentage of the county population that is of male gender (Male), which may not be a major factor in business activity but could still help control for some county effects nonetheless; the percentage of the county population that is considered white race (White) by Census definition, which follows similar studies in attempting to capture the demographics of a particular county. We also use two dummy variables to control for the existing sales tax environment in the contiguous region. Greater Tax is equal to 1 if the average combined sales tax rate is greater than the county's combined sales tax rate and 0 otherwise. Lower Tax is equal to 1 if the average combined sales tax rate is less than the county's combined sales tax rate and 0 otherwise. These control for whether the county is located in a high tax environment or a low tax environment, with the understanding that the impact of county's sales tax rate change on the business activity could be driven by the broader tax environment in the contiguous region. Table 1 gives an overview of the dependent and independent variables, their descriptions, sources, and further information about the specification of the variables. Table 2 shows the summary statistics for these variables as well.

\footnotetext{
${ }^{11}$ This variable also controls for the size of the entire labor market area.
} 


\section{Empirical Specification}

The spatial regression specification is used to analyze the implications of sales tax rate differentials between different counties. Different spatial regression models have been developed to capture different aspects of spatial dependence. For example, the spatial lag model is used to understand the spatial effects on the dependent variable where the dependent variable could be an economic activity or some government policy. The spatial error model is used to deal with the spatial correlation in the error term. While there are some other models such as spatial Durbin (SDM) which adds the average values of the neighbors for the independent variables to the model, spatial lag and spatial error models are the two most popular models.

Take spatial lag model as the example. Our spatial lag model is defined as follows:

$$
\text { Business Activity } y_{i t}=\alpha_{0}+\boldsymbol{\rho} \boldsymbol{W} y_{i t}+\beta_{1} \text { Rate }_{i t}+\boldsymbol{X}_{i t-1} \beta_{2}+\gamma_{i}+\tau_{t}+\varepsilon_{i t}
$$

As previously discussed $y_{i t}$ represents all the variations of dependent variables, separated by NAICS sector (Total, Manufacturing, Retail) and business metric (Annual Payroll, Employment, Establishments). $\boldsymbol{W}$ denotes the spatial weighting matrix which is generated using the inverse distance rules and is normalized. $\rho$ denotes the spatial effects. $\boldsymbol{X}$ is the vector of control variables containing Corporate, Individual, Personal, Labor, Unemployment, Working Age, Senior, Male, White, Greater Tax and Lower Tax. Control variable $\boldsymbol{X}$ is lagged during the regression. Finally, each year in the panel data set is controlled for by time dummies $(\tau)$, and $\gamma$ represents the fixed effects controlled for in the model by each individual county.

For the appropriate spatial regression model, we perform the standard LM-error and LM-lag tests to choose between the spatial lag and spatial error model. ${ }^{12}$ In results not reported here, but are available from the authors upon request, we reject the null hypothesis of zero spatial dependence. We further conducted the robust-LM test. The robust LM test statistic for the spatial lag model is still significant, while the one for the spatial error model is not. Hence the spatial lag model is preferred.

There are also different ways to generate the spatial weighting matrix. The spatial regression model could be sensitive to the choice of the spatial weighting matrix. We have tried three different spatial weighting based on contiguity, inverse distance, and nonparametric kernel density estimation. We decided to use the one based on contiguity which is the most straightforward weighting method.

\footnotetext{
${ }^{12}$ We have gone through the following steps to choose between SAR and SEM models: a) If both LMerror and LM-lag fail the LM tests, there may not be any need to examine spatial effects. b) If only one test result can be rejected, we choose the corresponding model as our candidate. c) If Both LM-Lag and LMerror tests reject the null hypothesis, that would mean both models can be possible candidates. To further decide which model is a better fit, we also conduct the robust LM test. We choose the model whose robust test statistic is rejected. If both test statistics reject the robust test, we then choose the one with the higher test statistic value.
} 
Spatial weighting depends on whether the two counties share a boundary. If two counties share a border, the matrix assigns 1 to the neighboring county. The resulting weighting matrix is row normalized. The contiguity weighting matrix is used to focus on the spatial effects within contiguous regions. Results based on the other two spatial weighting methods are not reported here but are available from the authors upon request.

\section{Summary Statistics}

In the United States, five out of the fifty states do not impose a general sales tax rate $^{13}$, and eighteen out of the fifty states analyzed do not have or allow a county-level general sales tax rate ${ }^{14}$, and thus have no sales tax rates available at the county-level. Although, this does not mean that there are no sales taxes instituted for other jurisdictions, including municipal (city), fire, education, and other special district sales tax rates that do not necessarily apply to an entire county. The summary statistics reveal some interesting facts about the U.S. sales tax as a whole for this period of the years 2002 through 2011. The national average county sales tax rate is $0.73 \%$, the average state sales tax rate is $5.18 \%$, and the average combined state \& county sales tax rate is about $5.91 \%$ for any given county. Furthermore, the state sales tax rate variable has a larger standard deviation than the county sales tax rate, indicating the state sales tax rate has more volatility (movement) respectively than the county sales tax rate over this time period, and much more variation across states. This could easily be attributable to the scale of state sales taxes, however. State sales tax rates are generally higher respectively than county sales tax rates. Generally, state sales tax rates do not change often, however this indicates that when they do, they possibly change more in total percentage (or scale) than county sales tax rates do.

Table 3 provides a list of the number of counties that have a county sales tax rate by state category. The table further shows some summary statistics of the county sales tax rate by state. The total of counties with some form of county sales tax rate shows an increase of 134 new counties with a sales tax rate from the year 2002 to 2011, and by 2011 at least $52 \%$ of county sales tax rates are non-zero.

An interesting case of note is the Commonwealth of Virginia, which had a local county sales tax rate of one percent for all counties within the state during the time period of this study. For this reason the data was accounted for as part of the state sales tax rate

\footnotetext{
${ }^{13}$ Those are Alaska, Delaware, Montana, New Hampshire and Oregon.

${ }^{14}$ Connecticut, Delaware, Indiana, Kentucky, Maine, Maryland, Massachusetts, Michigan, Mississippi, Montana, New Hampshire, New Jersey, Oregon, Rhode Island, South Dakota, Vermont, Virginia (special case), West Virginia.
} 
data acquired by the author ${ }^{15}$, utilizing it as a statewide, mandated tax rate, instead of accounting for it individually by county. This is also of note, since most states have statutes that control the abilities and limitations of lower-level governments, meaning that they are not necessarily free to impose the sales tax rates that they want, when they want. This means that comparisons at a national level is somewhat restricted by the restrictions of the local governments authority within a particular state.

We also see a significant association between the county sales tax rate (County Rate) and the state sales tax rate (State Rate) of -0.2063 , indicating that there could be some form of a trade-off between the two tax rates. This is consistent with the literature and economic theory in that the two government entities, regardless of what the tax is being collected for, are competing for the same tax base, resulting in what is called a vertical externality ${ }^{16}$. Further, in nearly all states, the sub-state jurisdictions are at the discretion of state law for limitations and abilities to set their own sales tax rates. Being that most states have their own sales tax rates ${ }^{17}$, they are going to be cautious in allowing the lower jurisdictions to institute an extra similar tax on top of theirs, which would thus be enabling a sort of "crowding out" effect on their own established sales taxation

Figures 1-6 show the variation in state, county and combined sales tax rates across different geographic locations and also across time. Figure 1 shows the total of these relations for all year observations included in the study, simply to show the total concentration over a period of time. This definitely concurs some of the basic evidence of a potential "trade-off" between state and local sales taxes and the vertical externality involved, further stressing the need for caution with the rise of local sales taxes.

In Figure 2, we can see the average increasing trend in the county sales tax rates (County Rate) over this time period. Figure 3 gives the same view of the average state sales tax rate (State Rate) over the same time period, and then Figure 4 gives the average combined state $\&$ county sales tax rate (Combined Rate) trend $^{18}$. All of these averages display an increasing trend, or reliance, in sales taxation by governments. This is especially true for the state sales taxes beginning after the economic recession of 2008 , whereas the average county sales tax rate exhibits a steadier, and unaffected increase.

\footnotetext{
${ }^{15}$ This $1 \%$ statewide county rate had already been accounted for as part of the state sales tax rate collected from the Book of the States (The Council of State Governments, 1935-). Since they followed this method of applying it similarly to a state rate, then I decided to follow the same method, and thus, the county rate for Virginia appears as part of the state rate. This should make no difference at least in the models using a combined state \& county rate. Recently, in 2013 , the county level local sales tax rates have changed in specific counties in Virginia, which could complicate this greatly, however these changes occur for time periods after that of this study. This may be interesting to see what effect these changes have within Virginia's business economy in the future as a natural experiment.

${ }^{16}$ Agrawal (forthcoming) addresses the concepts of vertical, horizontal, and postulates a "diagonal" externality as well in a frame of local sales taxation.

${ }^{17}$ Alaska is the only state that has sales tax rates at jurisdictions below the state without itself having a state sales tax rate also.

18 These average trends are only indicative of the behavior of those counties and states that actually have a non-zero sales tax rate.
} 
The maps in Figures 5 and 6 give a visual overview of the entire U.S. by county. Included are the end points of the data set (2002 and 2011) by combined state \& county sales tax rate in order to provide the best visual representation of the varying degree of sales tax rate usage throughout the U.S. over this time period.

\section{Regression Results}

Regression results for the annual payroll variable (Annual Payroll) can be found in Table 4. The results for the Combined Rate appear to be similar regardless of the regression specification. Both direct and indirect results show a negative and significant association between the combined sales tax rate and total annual payroll in county businesses. While most of the potential impact of the sales tax rate changes or differences is due to direct reduced business activity in the county, there is also a smaller potential indirect impact through business activity that is lost to contiguous counties. The coefficient for the total effect shows that for every one-percentage point increase in the combined sales tax rate, annual county payroll (per capita) decreases by about $0.9 \%$. When we restrict the dataset to include only the states with sales tax we see slightly greater coefficient estimates for the Combined Rate. For example, the corresponding decrease in annual county payroll (per capita) is now about $0.95 \%$. These results show a clear negative and significant association between the combined state and county sales tax rate and total annual payroll. At the same time the economic significance of these results is quite different. The estimated coefficients would translate into about $\$ 7$ million decrease in annual payroll in the county that is associated with a one-percentage increase in the combined rate. That is less than $0.5 \%$ of average county annual payroll. Considering also that the average county sales tax rate is about $0.7 \%$, the economic impact could be even smaller.

The annual payroll regression results for the manufacturing sector shown in Table 5 show qualitatively similar but significantly stronger results. The coefficient estimates for Combined Rate in (1) and (2) are more than twice as big as the comparable ones from Table 4. This could be indicating negative repercussions in the form of a change in the county's business structure from manufacturing to some form of retail trade or service. With stronger presence of business to business sales in the manufacturing we may indeed expect a greater potential impact which the results in Table 5 are pointing to. For a onepercentage point increase in the Combined Rate, we see about a $2 \%$ decrease in annual manufacturing payroll per capita. Again, these results show a clear negative association between the combined state and county sales tax rate and annual payroll in manufacturing but the economic significance is less pronounced. The estimated decrease in manufacturing payroll would be about $\$ 3.7$ million, or less than $2 \%$ of average county manufacturing payroll. Nonetheless, these results show particularly stronger negative association between sales taxes and payroll in the manufacturing sector.

The annual payroll regression results for the retail trade sector are shown in Table 6. Combined Rate is not consistently negative, and it is no longer statistically significant. Overall, the county annual payroll seems to be negatively associated with the combined state and county sales tax rate, with the majority of the potential impact concentrated on 
the manufacturing sector and no significant retail sector impact. It is not clear, however, if the potential impact from sales tax rate differences or changes is economically significant particularly since most county sales tax rates and changes are less than one percent.

Regression results for estimations of the employment variable (Employment) can be found in Tables 7-9. The results for the total employment (Total Employment) regressions appear to less clear and definitely less significant than the ones for the annual payroll. These regressions show negative and significant result for the Combined Rate variable only in the regression with the total employment so the results are not as robust as the ones for the annual payroll. It is likely that payroll is potentially the first item that companies consider in response to sales tax rate changes.

Regression results for the number of establishments (Establishments) can be found in Tables 10-15. Tables 10-12 show results for all establishments whereas the Tables 13-15 show the ones for only the small establishments that have less than 10 employees. ${ }^{19}$ The results are harder to interpret, considering the lack of significant coefficients for Combined Rate in a number of these regressions. The results that are significant show that the number of retail establishments and small establishments are associated negatively with the combined sales tax rate compared to larger establishments and the manufacturing establishments. Statistically significant coefficient estimates for Combined Rate in Tables 12, 13 and 15 show that for one-percentage point increase in the sales tax rate there could be up to $0.77 \%$ decrease in the number of retail establishments per capita, $0.9 \%$ decrease in the number of total small establishments per capita, and $0.9 \%$ decrease in the number of small retail establishments per capita. These translate into decreases of 3 retail (and small retail) establishments and between 7 and 16 total small establishments on average per county, which constitute less than $1 \%$ of total establishments (or small establishments) in the county. Again, the economic significance of potential impacts is much less pronounced.

Results for other control variables are mostly as expected in the regressions we discussed so far. There is mostly a robust positive relationship between variables used to capture different aspects of economic activity in counties and the business activity. We see positive and significant results for county personal income (Personal), size of the labor market area (Labor), and the share of the working age population (Working Age), and negative and significant results for county unemployment rate (Unemployment). All other results are either not significant or not consistent in terms of the direction or significance of the relationships. It may be surprising to see that other tax rate variables (Corporate and Individual) are not significant, except in few of the regressions, but that may be due to the fact that those only vary at the state level and may be capturing a variety of state level effects.

\footnotetext{
${ }^{19}$ Our focus is on the smallest size establishments since they are the largest group (about $70 \%$ of all establishments) and also they are the ones that are more likely to respond to even small tax rate changes.
} 


\section{Conclusion}

In this paper, we have looked at the relationship between state and county combined sales tax rates and the business activity in all counties in the United States. We found significantly negative association between the combined sales tax rate and annual payroll of businesses particularly in the manufacturing sector. Spatial effects, in the form of possible spillovers from business activity in the contiguous region, are also found to be stronger when payroll is used as an indicator of business activity. While we found no significant relationship with employment, there is statistically significant negative association with retail establishments and small establishments with less than 10 employees.

While the economic significance of these results is not overwhelming, the evidence points to potential issues with sales taxation for the policymakers regarding particularly business activity in the manufacturing and retail sectors. While one flag is for annual payroll in manufacturing business, another is for the number of establishments, particularly small establishments, in the retail sector.

One of the missing components of this study that is widely used in the literature is that of instrumental variables (IV) regression technique. Some of the studies in the tax competition literature uses some form of IV regressions to eliminate endogeneity inherent in sales tax rate estimations. This was described previously and covered as to why it would be difficult to utilize this form of estimation with this type of data, as justifying an instrument at lower levels of data collection (county, municipal, etc.) becomes much more difficult, considering the data collection issues still prevalent today. Some have been able to do this to varying degrees at the state level or with case-studies, but one possible extension of this literature would be to take the IV approach. Currently, it does not seem feasible with the available data.

Another possible extension is regarding the use of more detailed sales tax rates. Although counties have become key in the increases in sales taxes over recent decades and sales taxation below the state level has not been extensively covered. It may be possible to include more sales tax types, structural detail and local jurisdictions in a study in the future. This would undoubtedly contribute further to this literature. 


\section{References}

Agrawal, D. R. (forthcoming). Inter-Federation Competition: Sales Taxation with Multiple Federations. Journal of Urban Economics.

Agrawal, D. R. (2014). LOST in America: Evidence on Local Sales Taxes from National Panel Data. Regional Science and Urban Economics, 49: 147-163.

Almendrala, A. (2011, October 6). Northern California Vs. Southern California: Who Runs The Golden State? Huffington Post. Los Angeles, California, USA. Retrieved from http://www.huffingtonpost.com/2011/10/06/northern-californiavs-southern-california_n_995414.html

American Enterprise Institute. (2012, April). Public Opinion on Taxes: 1937 to Today. (K. Bowman, \& A. Rugg, Eds.) AEI Public Opinion Studies.

Asplund, M., Friberg, R., \& Wilander, F. (2007). Demand and distance: Evidence on cross-border shopping. Journal of Public Economics, 91, 141-157.

Bartik, T. J. (1991, December). Boon or Boondoggle? The Debate Over State and Local Economic Development Policies. In W. U. Institute, In Who Benefits from State and Local Economic Development Policies? (pp. 1-16). Kalamazoo, MI: W.E. Upjohn Institute for Employment Research.

Bruce, D., \& Fox, W. F. (2000, December). E-Commerce in the Context of Declining State Sales Tax Bases. National Tax Journal, 53(4, Part 3), 1373-1388.

Brunori, D. (2007). Local tax policy: a federalist perspective (2nd ed.). Washington, D.C.: The Urban Institute Press.

Brunori, D. (2011). State Tax Policy: A Political Perspective (3rd ed.). Washington, D.C.: The Urban Institute Press.

Burnes, D., Neumark, D., \& White, M. J. (2012, February). Fiscal Zoning, Sales Taxes, and Employment: Do Higher Sales Taxes Lead to More Jobs in Retailing and Fewer Jobs in Manufacturing? Institute for the Study of Labor(Discussion Paper No. 6383).

Callan, J., \& Moffat, A. (2012). Panel on Use of Proprietary Data. Special Interest Group on Information Retrieval Forum, 10-18.

Carlton, D. W. (1983, August). The Location and Employment Choices of New Firms: An Econometric Model with Discrete and Continuous Endogenous Variables. The Review of Economics and Statistics, 65(3), 440-449.

Carroll, R., \& Wasylenko, M. (1994). DO STATE BUSINESS CLIMATES STILL MATTER? - EVIDENCE OF A STRUCTURAL CHANGE. National Tax Journal, 47(1), 19 - 37.

Due, J. F. (1957). Sales Taxation. Urbana: University of Illinois Press.

Due, J. F., \& Mikesell, J. L. (1994). Sales taxation: State and local structure and administration. Washington, DC: The Urban Institute Press.

Duggan, B. (2012, January 23). The truth about STAR bonds. Reno Gazette-Journal. Reno, NV. Retrieved from http://www.rgj.com/article/20120124/NEWS/301160010/The-truth-about-STARbonds

Duggan, B. (2013, January 23). States' STAR bonds vary. Reno Gazette-Journal. Retrieved from http://www.rgj.com/article/20120124/NEWS/301230022/1321?nclick_check=1 
Fisher, R. C. (2007). State and Local Public Finance (3rd ed.). Mason, OH: Thomson South-Western.

Fox, W. F. (1986). Tax Structure and the Location of Economic Activity Along State Borders. National Tax Journal, 39, 387-401.

Fox, W. F. (2003, September). History and Economic Impact of the Sales Tax. (J. Janata, Ed.) Sales Taxation.

Fox, W. F., \& Murray, M. N. (2004). Do Economic Effects Justify the Use of Fiscal incentives? Southern Economic Journal, 71(1), 78-92.

Frydman, R., Murphy, K., \& Rapaczynski, A. (1998). Capitalism with a Comrade's Face: Studies in the Postcommunist Transition. Central European University Press.

Hageman, A. M. (2012). A $21^{\text {st }}$ Century Literature Review of Sales and Use Taxes for Accountants. Advances in Accounting Behavioral Research, 15, 167-214. doi:10.1108/S1475-1488(2012)0000015011

Holder, H. D., Giesbrecht, N., Horverak, Ø., Nordlund, S., Norström, T., Olsson, O., . . . Skog, O.-J. (1995). Potential consequences from possible changes to Nordic retail alcohol monopolies resulting from European Union membership. Addiction, 90, $1603 \pm 1618$.

Isidore, C. (2008, December 1). It's official: Recession since Dec. '07. CNN Money. Retrieved from http://money.cnn.com/2008/12/01/news/economy/recession/index.htm

Jacobs, J. P., Ligthart, J. E., \& Vrijburg, H. (2010). Consumption Tax Competition Among Governments: Evidence from the United States. International Tax and Public Finance, 17, 271-294.

Johnson, C. L., \& Man, J. Y. (Eds.). (2001). Tax increment financing and economic development: uses, structures, and impacts. Albany, NY: State University of New York Press.

Krmenec, A. J. (1991). Sales Tax as Property Tax Relief? The Shifting Onus of Local Revenue Generation. Professional Geographer, 19, 60-67.

Krudy, E. (2013, April 18). How a student took on eminent economists on debt issue and won. Retrieved from Reuters.com: http://www.reuters.com/article/2013/04/18/us-global-economy-debt-herndonidUSBRE93H0CV20130418

Luna, L. (Spring 2004). Local Sales Tax Competition and the Effect on County Governments' Tax Rates and Tax Bases. The Journal of the American Taxation Association, 26(1), 43-61.

Luna, L., Bruce, D. J., \& Hawkins, R. R. (2007, March). Maxing Out: An Analysis of Local Option Sales Tax Rate Increases. National Tax Journal, 60(1).

Martin, D. (2009, September 16). STAR, TIF... WTF? The Pitch Blogs. Retrieved from http://www.pitch.com/plog/archives/2009/09/16/star-tif-wtf

McAllister, H. (1961). The Border Tax Problem in Washington. National Tax Journal, $14,362-374$.

McLure, C. E. (2000). Rethinking State and Local Reliance on the Retail Sales Tax: Should We Fix the Sales Tax or Discard It? BRIGHAM YOUNG UNIVERSITY LAW REVIEW, 77, 77-137. 
Members of Advisory Commission on Intergovernmental Relations. (March 1995). TAX AND EXPENDITURE LIMITS ON LOCAL GOVERNMENTS. Indiana University, Center for Urban Policy and the Environment. Washington, DC: U.S. Advisory Commission on Intergovernmental Relations.

Mikesell, J. L. (1970). Central Cities and Sales Tax Rate Differentials: The Border City Problem. National Tax Journal, 23, 206-213.

Mikesell, J. L. (2012). State Tax Policy and State Sales Taxes: What Tax Expenditure Budgets Tell Us About Sales Taxes. The American Review of Public Administration, 42(2), $131-151$.

Mikesell, J. L., \& Zorn, K. C. (1986, July). Impact of the Sales Tax Rate on Its Base: Evidence from a Small Town. Public Finance Quarterly, 14(3), 329-338.

NACo. (2013). Overview of County Government. Retrieved from National Association of Counties: http://www.naco.org/Counties/learn/Pages/Overview.aspx

O'Sullivan, A., Sexton, T. A., \& Sheffrin, S. M. (1995). Property Taxes and Tax Revolts: The Legacy of Proposition 13. New York: Cambridge University Press.

Rogers, C. L. (2004). Local Option Sales Tax (LOST) Policy on the Urban Fringe. The Journal of Regional Analysis \& Policy, 34(1), 27-50.

Rohlin, S., Rosenthal, S., \& Ross, A. (2012). Tax Avoidance and Business Location in a State Border Model. Unpublished Manuscript. Syracuse, NY: Maxwell School, Syracuse University.

Snodgrass, D. W., \& Otto, D. M. (1990). Analysis of Local Sales Taxation in Rural Areas: An Oklahoma Case Study. Growth and Change, 21, 34-45.

Stock, J. H., \& Watson, M. W. (2008, January). Heteroskedasticity-Robust Standard Errors for Fixed Effects Panel Data Regression. Econometrica, 76(1), 155-174.

The Council of State Governments. (1935-). The Book of the States. Retrieved from http://knowledgecenter.csg.org/drupal/category/content-type/content-type/bookstates

The Royal Household. (2013). Charles I (r. 1625-1649). Retrieved September 9, 2013, from The Official Website of the British Monarchy: http://www.royal.gov.uk/HistoryoftheMonarchy/KingsandQueensoftheUnitedKin gdom/TheStuarts/CharlesI.aspx

Thompson, J. P., \& Rohlin, S. M. (2012, December). The Effect of Sales Taxes on Employment: New Evidence from Cross-Border Panel Data Analysis. National Tax Journal, 65(4), 1023-1042.

Tosun, M. S., \& Skidmore, M. L. (2007). Cross-Border Shopping and the Sales Tax: An Examination of Food Purchases in West Virginia. The B.E. Journal of Economic Analysis \& Policy, 7(1 (Topics)), Article 63.

U.S. Dept. of Commerce, Bureau of the Census. (1992). CONTIGUOUS COUNTY FILE, 1991: [UNITED STATES] [Computer file]. Washington, D.C.: Ann Arbor, MI: Inter- university Consortium for Political and Social Research [distributor]. doi:10.3886/ICPSR09835.v1

U.S. Dept. of Commerce, Bureau of the Census. (2013). North American Industry Classification System: 2007 NAICS. Retrieved 2013, from United States Census Bureau: http://www.census.gov/cgi-bin/sssd/naics/naicsrch?chart=2007

Walsh, M. J., \& Jones, J. D. (1988). More evidence on the "Border Tax" Effect: The Case of West Virginia, 1979-84. National Tax Journal, 41, 491-601. 
Wassmer, R. W., \& Anderson, J. E. (2001, May). Bidding for Business: New Evidence on the Effect of Locally Offered Economic Development Incentives in a Metropolitan Area. ECONOMIC DEVELOPMENT QUARTERLY, 132-148.

Wasylenko, M., \& McGuire, T. (1985). JOBS AND TAXES: THE EFFECT OF BUSINESS CLIMATE ON STATES' EMPLOYMENT GROWTH RATES. National Tax Journal, 38(4), 497-511.

Wong, J. D. (1996). The Impact of Local Option Sales Taxes on Retail Sales, Employment, Payrolls, and Establishments: The Case for Kansas. The Review of Regional Studies, 26, 165-176.

Zhao, Z. J., \& Hou, Y. (Spring 2008). Local Option Sales Taxes and Fiscal Disparity: The Case of Georgia Counties. Public Budgeting \& Finance, 28(1), 39-57. 
Table 1: Description of Variables

\begin{tabular}{|c|c|c|c|c|}
\hline Economic Variable & Variable Description & Original Units & Source & Econometric Units \\
\hline $\begin{array}{l}\text { Denendent } \\
\text { Annual Payroll }\end{array}$ & Annual Payroll (by NAICS codes) ${ }^{20}$ & Thousands of $\$$ & $\begin{array}{l}\text { U.S. Census Bureau County } \\
\text { Business Patterns }{ }^{21}\end{array}$ & Natural Logarithm of Per Capita \\
\hline Employment & Mid-March Employees (by NAICS codes) ${ }^{22}$ & Nominal & $\begin{array}{l}\text { U.S. Census Bureau County } \\
\text { Business Patterns }\end{array}$ & Natural Logarithm of Per Capita \\
\hline Establishments & Number of Establishments (by NAICS codes) ${ }^{23}$ & Nominal & $\begin{array}{l}\text { U.S. Census Bureau County } \\
\text { Business Patterns }\end{array}$ & Natural Logarithm of Per Capita \\
\hline \multicolumn{5}{|l|}{ Explanatory } \\
\hline State Rate & State Sales Tax Rate & Percentage & The Book of the States 24 & Percentage \\
\hline County Rate & County Sales Tax Rate & Percentage & Various Sources & Percentage \\
\hline $\begin{array}{l}\text { Combinea Kate } \\
\text { Corporate }\end{array}$ & Top Marginal State Corporate Income Tax Rate & Percentage & The Book of the States & Percentage \\
\hline Individual & Top Marginal State Individual Income Tax Rate & Percentage & The Book of the States & Percentage \\
\hline Personal & Personal Income & Thousands of \$ & Bureau of Labor Statistics ${ }^{25}$ & Natural Logarithm of Per Capita \\
\hline Labor & Annual Average Labor Force & Nominal & Bureau of Labor Statistics & Natural Logarithm of Per Capita \\
\hline Unemployment & Annual Average Unemployment Rate & Percentage & Bureau of Labor Statistics & Percentage \\
\hline Working Age & Percent of Population Age 20 to 64 & Percentage & U.S. Census Bureau ${ }^{26}$ & Percentage \\
\hline Senior & Percent of Population Age 65 and Older & Percentage & U.S. Census Bureau & Percentage \\
\hline Male & Percent of Population Male Gender & Percentage & U.S. Census Bureau & Percentage \\
\hline White & Percent of Population White Race & Percentage & U.S. Census Bureau & Percentage \\
\hline Greater Tax & $\begin{array}{l}\text { Greater average combined sales tax rate in } \\
\text { contiguous counties }\end{array}$ & $\begin{array}{l}1 \text { if greater; } 0 \\
\text { otherwise }\end{array}$ & Computed by Authors & $\begin{array}{l}1 \text { if greater; } 0 \\
\text { otherwise }\end{array}$ \\
\hline Lower Tax & $\begin{array}{l}\text { Lower average combined sales tax rate in } \\
\text { contiguous counties }\end{array}$ & $\begin{array}{l}1 \text { if lower; } 0 \\
\text { otherwise }\end{array}$ & Computed by Authors & $\begin{array}{l}1 \text { if lower; } 0 \\
\text { otherwise }\end{array}$ \\
\hline
\end{tabular}

20 Total (Total Annual Payroll); Manufacturing (Manufacturing Annual Payroll); Retail Trade (Retail Annual Payroll).

${ }^{21}$ Data from the United States Census Bureau County Business Patterns can be found on the internet at http://www.census.gov/econ/cbp/.

22 Total (Total Employment); Manufacturing (Manufacturing Employment); Retail Trade (Retail Employment).

${ }^{23}$ Total (Total Establishments); Manufacturing (Manufacturing Establishments); Retail Trade (Retail Establishments).

${ }^{24}$ Published by The Council of State Governments, obtainable through http://knowledgecenter.csg.org/drupal/view-content-type/1219.

${ }^{25}$ Data from the United States Bureau of Labor Statistics (BLS) can be found on the internet at http://www.bls.gov/.

${ }^{26}$ Data from the United States Census Bureau can be found on the internet at http://www.census.gov/. 
Table 2: Summary Statistics

\begin{tabular}{|c|c|c|c|c|c|}
\hline Variable & Observations & Mean & $\begin{array}{l}\text { Standard } \\
\text { Deviation }\end{array}$ & Minimum & Maximum \\
\hline \multicolumn{6}{|l|}{ Dependent } \\
\hline Total Annual Payroll & 29603 & 1.9289 & 0.6274 & -2.086 & 4.9077 \\
\hline Total Employment & 29511 & -1.404 & 0.4742 & -5.3534 & 0.5731 \\
\hline Total Establishments & 29785 & -3.803 & 0.3567 & -5.8156 & -2.1035 \\
\hline Manufacturing Annual Payroll & 23925 & 0.223 & 1.0661 & -5.2074 & 2.9879 \\
\hline Manufacturing Employment & 23357 & -3.316 & 0.9252 & -8.149 & -0.5108 \\
\hline Manufacturing Establishments & 29159 & -6.93 & 0.5508 & -9.7745 & -4.8451 \\
\hline Retail Annual Payroll & 29126 & -0.281 & 0.5455 & -3.8875 & 2.1683 \\
\hline Retail Employment & 28715 & -3.241 & 0.4452 & -6.3084 & -1.2592 \\
\hline Retail Establishments & 29740 & -5.555 & 0.3531 & -7.6326 & -3.3689 \\
\hline \multicolumn{6}{|l|}{ Explanatory } \\
\hline State Rate & 31410 & 0.0518 & 0.0148 & 0 & 0.0825 \\
\hline County Rate & 31410 & 0.0073 & 0.0104 & 0 & 0.07 \\
\hline Combined Rate & 31410 & 0.0591 & 0.0163 & 0 & 0.105 \\
\hline Corporate & 31410 & 0.0615 & 0.0297 & 0 & 0.12 \\
\hline Individual & 31410 & 0.0504 & 0.0288 & 0 & 0.11 \\
\hline Personal & 30840 & 3.3782 & 0.243 & 2.3952 & 4.8262 \\
\hline Labor & 31372 & -0.721 & 0.1372 & -1.949 & 0.0654 \\
\hline Unemployment & 31386 & 0.0651 & 0.0282 & 0 & 0.299 \\
\hline Working Age & 31360 & 0.578 & 0.0345 & 0.4429 & 0.8284 \\
\hline Senior & 31360 & 0.1535 & 0.0418 & 0.0168 & 0.4603 \\
\hline Male & 31360 & 0.4986 & 0.0214 & 0.4263 & 0.7212 \\
\hline White $^{27}$ & 30820 & 0.8648 & 0.1616 & 0.0261 & 1.0294 \\
\hline Greater Tax & 31360 & 0.3229 & 0.4676 & 0 & 1 \\
\hline Lower Tax & 31360 & 0.3123 & 0.4635 & 0 & 1 \\
\hline
\end{tabular}

${ }^{27}$ The maximum value on White is a pristine example of the issues of data collection. Since the data on white population had to be divided by the data available on total population, and both are estimates routinely updated by the Census Bureau, then there is a possibility that the estimates may not match in totals, and you get a situation where a county's estimated white population is larger than the estimated total population. This was a result of the estimated data gathered, and the procedures to make the percentages from the gathered data were double-checked to confirm this error was not a result of authors' calculations. 
Table 3: Summary of Counties with County Sales Tax Rates ${ }^{28}$ by State

\begin{tabular}{|c|c|c|c|c|c|c|c|c|c|c|}
\hline \multicolumn{11}{|c|}{ Summary Statistics by State } \\
\hline State $^{29}$ & 2002 & 2003 & 2004 & 2005 & 2006 & 2007 & 2008 & 2009 & 2010 & 2011 \\
\hline Alabama & 64 & 65 & 66 & 66 & 66 & 66 & 66 & 66 & 66 & 66 \\
\hline Alaska & 13 & 13 & 13 & 13 & 13 & 13 & 13 & 13 & 13 & 14 \\
\hline Arizona & 14 & 14 & 14 & 14 & 14 & 15 & 15 & 15 & 15 & 15 \\
\hline Arkansas & 72 & 73 & 73 & 73 & 73 & 73 & 72 & 72 & 72 & 72 \\
\hline California & 24 & 24 & 24 & 23 & 24 & 26 & 26 & 26 & 27 & 27 \\
\hline Colorado & 49 & 49 & 50 & 49 & 49 & 50 & 52 & 52 & 52 & 51 \\
\hline Florida & 43 & 47 & 48 & 50 & 50 & 50 & 51 & 53 & 54 & 55 \\
\hline Georgia & 154 & 153 & 154 & 154 & 154 & 154 & 154 & 154 & 154 & 154 \\
\hline Hawaii & & & & & & 1 & 1 & 1 & 1 & 1 \\
\hline Idaho & & & 1 & 1 & & & & & & \\
\hline Illinois & 19 & 19 & 23 & 26 & 35 & 37 & 40 & 42 & 45 & 47 \\
\hline Iowa & 58 & 62 & 72 & 74 & 78 & 81 & 84 & 88 & 92 & 92 \\
\hline Kansas & 78 & 77 & 78 & 79 & 86 & 86 & 86 & 86 & 86 & 87 \\
\hline Louisiana & 63 & 63 & 63 & 63 & 63 & 63 & 63 & 63 & 63 & 63 \\
\hline Minnesota & & & & & & 1 & 1 & 1 & 2 & 2 \\
\hline Missouri & 115 & 115 & 115 & 115 & 115 & 115 & 115 & 115 & 115 & 115 \\
\hline Nebraska & & & & 1 & 1 & 1 & 1 & 1 & 1 & 1 \\
\hline Nevada & 9 & 9 & 10 & 10 & 10 & 10 & 10 & 12 & 12 & 12 \\
\hline New & 33 & 33 & 33 & 33 & 33 & 33 & 33 & 33 & 33 & 33 \\
\hline New York & 62 & 62 & 62 & 62 & 62 & 62 & 62 & 62 & 62 & 62 \\
\hline North & 100 & 100 & 100 & 100 & 100 & 100 & 100 & 100 & 100 & 100 \\
\hline North & 2 & 2 & 1 & 1 & 2 & 3 & 3 & 3 & 3 & 3 \\
\hline Ohio & 87 & 88 & 88 & 88 & 88 & 88 & 88 & 88 & 88 & 87 \\
\hline Oklahoma & 65 & 67 & 66 & 66 & 69 & 70 & 72 & 73 & 75 & 76 \\
\hline Pennsylva & 2 & 2 & 2 & 2 & 2 & 2 & 2 & 2 & 2 & 2 \\
\hline South & 27 & 27 & 27 & 27 & 29 & 30 & 31 & 31 & 32 & 32 \\
\hline Tennessee & 95 & 95 & 95 & 95 & 95 & 95 & 95 & 95 & 95 & 95 \\
\hline Texas & 120 & 120 & 121 & 121 & 122 & 122 & 123 & 123 & 123 & 123 \\
\hline Utah & 26 & 26 & 26 & 26 & 26 & 26 & 29 & 29 & 29 & 29 \\
\hline Washingto & 36 & 36 & 36 & 36 & 36 & 36 & 39 & 39 & 39 & 39 \\
\hline Wisconsin & 55 & 57 & 58 & 58 & 58 & 59 & 60 & 61 & 61 & 62 \\
\hline Wyoming & 18 & 18 & 18 & 18 & 19 & 19 & 18 & 20 & 20 & 20 \\
\hline Total & 1503 & 1516 & 1537 & 1544 & 1572 & 1587 & 1605 & 1619 & 1632 & 1637 \\
\hline
\end{tabular}

${ }^{28}$ Based on County Rate variable.

${ }^{29}$ States not listed do not have county sales tax rates in the data set for this period of time. 
Table 4: Regression Results, Combined Rate, Annual Payroll, Total (with Spatial Lag Model)

\begin{tabular}{|c|c|c|c|c|c|c|}
\hline \multirow{2}{*}{$\begin{array}{c}\text { Total Annual } \\
\text { Payroll }\end{array}$} & & \multicolumn{3}{|c|}{ (2) } \\
\hline & Direct & Indirect & Total & Direct & Indirect & Total \\
\hline \multirow[t]{2}{*}{ Combined Rate } & $-0.706^{* * *}$ & $-0.195 * *$ & $-0.902 * *$ & $-0.760^{* *}$ & $-0.194 * *$ & $-0.954 * *$ \\
\hline & {$[0.326]$} & {$[0.095]$} & {$[0.416]$} & [0.329] & {$[0.090]$} & [0.412] \\
\hline \multirow[t]{2}{*}{ Corporate } & -0.04 & -0.011 & -0.052 & -0.063 & -0.016 & -0.079 \\
\hline & [0.147] & [0.042] & {$[0.188]$} & {$[0.145]$} & [0.038] & [0.182] \\
\hline \multirow[t]{2}{*}{ Individual } & $-0.848 * * *$ & $-0.235^{* * *}$ & $-1.083^{* * *}$ & $-0.493^{*}$ & -0.128 & $-0.620^{*}$ \\
\hline & [0.284] & [0.088] & [0.364] & [0.284] & {$[0.080]$} & {$[0.360]$} \\
\hline \multirow[t]{2}{*}{ Personal } & $0.365 * * *$ & $0.101 * * *$ & $0.467 * * *$ & $0.376^{* * *}$ & $0.096^{* * * *}$ & $0.471 * * *$ \\
\hline & [0.029] & [0.016] & {$[0.038]$} & {$[0.030]$} & [0.017] & {$[0.039]$} \\
\hline \multirow[t]{2}{*}{ Labor } & $0.633^{* * *}$ & $0.176^{* * * *}$ & $0.810 * * *$ & $0.614^{* * *}$ & $0.157 * * *$ & $0.772 * * *$ \\
\hline & {$[0.056]$} & [0.032] & {$[0.077]$} & [0.054] & [0.031] & {$[0.074]$} \\
\hline \multirow[t]{2}{*}{ Unemployment } & $-1.713 * * *$ & $-0.475^{* * *}$ & $-2.189 * * *$ & $-1.734 * * *$ & $-0.444 * * *$ & $-2.178 * * *$ \\
\hline & {$[0.130]$} & {$[0.077]$} & {$[0.173]$} & {$[0.134]$} & {$[0.081]$} & {$[0.178]$} \\
\hline \multirow[t]{2}{*}{ Working Age } & $1.577 * * *$ & $0.435^{* * * *}$ & $2.012 * * *$ & $1.743 * * *$ & $0.443 * * *$ & $2.186^{* * *}$ \\
\hline & [0.406] & {$[0.117]$} & {$[0.506]$} & {$[0.462]$} & {$[0.130]$} & {$[0.570]$} \\
\hline \multirow[t]{2}{*}{ Senior } & -0.025 & -0.007 & -0.032 & -0.055 & -0.013 & -0.068 \\
\hline & {$[0.400]$} & {$[0.115]$} & {$[0.513]$} & {$[0.453]$} & [0.119] & {$[0.570]$} \\
\hline \multirow[t]{2}{*}{ Male } & -0.266 & -0.073 & -0.339 & -0.181 & -0.045 & -0.226 \\
\hline & {$[0.511]$} & {$[0.144]$} & {$[0.653]$} & {$[0.512]$} & [0.133] & [0.644] \\
\hline \multirow[t]{2}{*}{ White } & 0.316 & 0.089 & 0.405 & $0.472 *$ & 0.122 & $0.594 *$ \\
\hline & {$[0.255]$} & {$[0.074]$} & {$[0.327]$} & {$[0.277]$} & {$[0.076]$} & [0.349] \\
\hline \multirow[t]{2}{*}{ Greater Tax } & -0.001 & 0 & -0.001 & -0.001 & 0 & -0.001 \\
\hline & {$[0.006]$} & {$[0.002]$} & {$[0.008]$} & {$[0.006]$} & {$[0.002]$} & {$[0.007]$} \\
\hline \multirow[t]{2}{*}{ Lower Tax } & $0.015^{* * *}$ & $0.004 * * *$ & $0.020 * * *$ & $0.016^{* * * *}$ & $0.004 * * *$ & $0.020 * * *$ \\
\hline & {$[0.005]$} & {$[0.002]$} & {$[0.007]$} & {$[0.005]$} & {$[0.001]$} & {$[0.007]$} \\
\hline \multirow[t]{2}{*}{ Spatial Effect } & $0.221 * * *$ & $0.221 * * *$ & $0.221 * * *$ & $0.207 * * *$ & $0.207 * * *$ & $0.207 * * *$ \\
\hline & {$[0.025]$} & {$[0.025]$} & {$[0.025]$} & {$[0.027]$} & {$[0.027]$} & {$[0.027]$} \\
\hline Fixed Effects & \multicolumn{3}{|c|}{ County } & \multicolumn{3}{|c|}{ County } \\
\hline Year Dummies & \multicolumn{3}{|c|}{ Yes } & \multicolumn{3}{|c|}{ Yes } \\
\hline $\begin{array}{c}\text { Only Sales Tax } \\
>0\end{array}$ & \multicolumn{3}{|c|}{ No } & \multicolumn{3}{|c|}{ Yes } \\
\hline $\mathbf{R}^{2}$ & \multicolumn{3}{|c|}{0.2493} & \multicolumn{3}{|c|}{0.2244} \\
\hline Observations & \multicolumn{3}{|c|}{18846} & \multicolumn{3}{|c|}{17820} \\
\hline
\end{tabular}

Robust standard errors in brackets

$*$ significant at $10 \%$; ** significant at 5\%; *** significant at $1 \%$ 
Table 5: Regression Results, Combined Rate, Annual Payroll, Manufacturing (with Spatial Lag Model)

\begin{tabular}{|c|c|c|c|c|c|c|}
\hline \multirow{2}{*}{$\begin{array}{l}\text { Manufacturing } \\
\text { Annual Payroll }\end{array}$} & \multicolumn{3}{|c|}{ (1) } & \multicolumn{3}{|c|}{ (2) } \\
\hline & Direct & Indirect & Total & Direct & Indirect & Total \\
\hline \multirow[t]{2}{*}{ Combined Rate } & $-1.471^{*}$ & $-0.369 *$ & $-1.840 * *$ & $-1.703 * *$ & $-0.433 * *$ & $-2.136^{* *}$ \\
\hline & {$[0.750]$} & {$[0.201]$} & [0.936] & {$[0.754]$} & [0.207] & [0.942] \\
\hline \multirow[t]{2}{*}{ Corporate } & 0.298 & 0.078 & 0.376 & 0.342 & 0.091 & 0.433 \\
\hline & {$[0.282]$} & {$[0.079]$} & {$[0.360]$} & {$[0.281]$} & [0.081] & [0.359] \\
\hline \multirow[t]{2}{*}{ Individual } & -0.538 & -0.141 & -0.679 & -0.482 & -0.132 & -0.614 \\
\hline & {$[0.767]$} & {$[0.203]$} & {$[0.964]$} & {$[0.743]$} & {$[0.202]$} & {$[0.940]$} \\
\hline \multirow[t]{2}{*}{ Personal } & $0.386^{* * *}$ & $0.098 * * *$ & $0.484 * * *$ & $0.364 * * *$ & $0.094 * * *$ & $0.458^{* * * *}$ \\
\hline & {$[0.088]$} & {$[0.030]$} & {$[0.113]$} & [0.090] & [0.031] & [0.116] \\
\hline \multirow[t]{2}{*}{ Labor } & $0.754 * * *$ & $0.192 * * *$ & $0.946 * * *$ & $0.759 * * *$ & $0.195^{* * *}$ & $0.954 * * *$ \\
\hline & [0.128] & [0.049] & [0.164] & {$[0.130]$} & {$[0.051]$} & {$[0.167]$} \\
\hline \multirow[t]{2}{*}{ Unemployment } & $-2.224 * * *$ & $-0.566^{* * *}$ & $-2.789 * * *$ & $-2.223 * * *$ & $-0.572 * * *$ & $-2.795^{* * *}$ \\
\hline & [0.283] & [0.131] & {$[0.368]$} & [0.289] & [0.135] & [0.377] \\
\hline \multirow[t]{2}{*}{ Working Age } & $2.420^{* *}$ & $0.607 * *$ & $3.027 * *$ & $2.832 * * *$ & $0.721 * * *$ & $3.552 * * *$ \\
\hline & [0.989] & [0.259] & [1.221] & [1.017] & {$[0.278]$} & [1.258] \\
\hline \multirow[t]{2}{*}{ Senior } & 1.094 & 0.281 & 1.375 & 1.407 & 0.365 & 1.772 \\
\hline & [1.127] & {$[0.302]$} & [1.421] & [1.143] & {$[0.315]$} & [1.446] \\
\hline \multirow[t]{2}{*}{ Male } & $-2.993^{*}$ & $-0.768^{*}$ & $-3.761^{*}$ & $-2.970^{*}$ & $-0.773^{*}$ & $-3.744 *$ \\
\hline & [1.560] & {$[0.431]$} & [1.964] & [1.624] & [0.459] & [2.055] \\
\hline \multirow[t]{2}{*}{ White } & 0.725 & 0.185 & 0.91 & 0.84 & 0.216 & 1.056 \\
\hline & {$[0.636]$} & [0.169] & {$[0.798]$} & {$[0.642]$} & {$[0.173]$} & [0.807] \\
\hline \multirow[t]{2}{*}{ Greater Tax } & 0.007 & 0.002 & 0.009 & 0.007 & 0.002 & 0.008 \\
\hline & {$[0.016]$} & [0.004] & {$[0.021]$} & {$[0.016]$} & [0.004] & {$[0.021]$} \\
\hline \multirow[t]{2}{*}{ Lower Tax } & 0.019 & 0.005 & 0.023 & 0.019 & 0.005 & 0.024 \\
\hline & {$[0.015]$} & [0.004] & {$[0.018]$} & {$[0.015]$} & [0.004] & {$[0.018]$} \\
\hline \multirow[t]{2}{*}{ Spatial Effect } & $0.205^{* * *}$ & $0.205^{* * *} *$ & $0.205^{* * *} *$ & $0.207 * * *$ & $0.207 * * *$ & $0.207 * * *$ \\
\hline & {$[0.030]$} & {$[0.030]$} & {$[0.030]$} & [0.030] & {$[0.030]$} & {$[0.030]$} \\
\hline Fixed Effects & \multicolumn{3}{|c|}{ County } & \multicolumn{3}{|c|}{ County } \\
\hline Year Dummies & \multicolumn{3}{|c|}{ Yes } & \multicolumn{3}{|c|}{ Yes } \\
\hline $\begin{array}{c}\text { Only Sales Tax } \\
>0\end{array}$ & \multicolumn{3}{|c|}{ No } & \multicolumn{3}{|c|}{ Yes } \\
\hline $\mathbf{R}^{2}$ & \multicolumn{3}{|c|}{0.01} & \multicolumn{3}{|c|}{0.0113} \\
\hline Observations & \multicolumn{3}{|c|}{12402} & \multicolumn{3}{|c|}{11844} \\
\hline
\end{tabular}

Robust standard errors in brackets

$*$ significant at $10 \%$; ** significant at $5 \%$; *** significant at $1 \%$ 
Table 6: Regression Results, Combined Rate, Annual Payroll, Retail Trade (with Spatial Lag Model)

\begin{tabular}{|c|c|c|c|c|c|c|}
\hline \multirow{2}{*}{$\begin{array}{c}\text { Retail Annual } \\
\text { Payroll }\end{array}$} & \multicolumn{3}{|c|}{ (1) } & \multicolumn{3}{|c|}{ (2) } \\
\hline & Direct & Indirect & Total & Direct & Indirect & Total \\
\hline \multirow[t]{2}{*}{ Combined Rate } & 0.108 & 0.032 & 0.14 & -0.003 & 0.001 & -0.002 \\
\hline & {$[0.371]$} & [0.107] & {$[0.476]$} & {$[0.375]$} & {$[0.100]$} & {$[0.474]$} \\
\hline \multirow[t]{2}{*}{ Corporate } & -0.138 & -0.038 & -0.176 & -0.175 & -0.045 & -0.22 \\
\hline & {$[0.164]$} & {$[0.047]$} & {$[0.211]$} & {$[0.165]$} & [0.044] & {$[0.208]$} \\
\hline \multirow[t]{2}{*}{ Individual } & $-0.553^{*}$ & $-0.157^{*}$ & $-0.709^{*}$ & -0.015 & -0.006 & -0.021 \\
\hline & [0.282] & {$[0.085]$} & {$[0.364]$} & {$[0.305]$} & [0.082] & {$[0.385]$} \\
\hline \multirow[t]{2}{*}{ Personal } & $0.271 * * *$ & $0.076^{* * *}$ & $0.348 * * *$ & $0.271 * * *$ & $0.071^{* * *}$ & $0.343^{* * *} *$ \\
\hline & {$[0.040]$} & {$[0.017]$} & {$[0.053]$} & {$[0.041]$} & {$[0.017]$} & {$[0.054]$} \\
\hline \multirow[t]{2}{*}{ Labor } & $0.254 * * *$ & $0.071 * * *$ & $0.325 * * *$ & $0.266^{* * *}$ & $0.069 * * *$ & $0.335^{* * *}$ \\
\hline & {$[0.060]$} & [0.019] & [0.076] & [0.061] & [0.018] & [0.076] \\
\hline \multirow[t]{2}{*}{ Unemployment } & $-0.850 * * *$ & $-0.239 * * *$ & $-1.089 * * *$ & $-0.882 * * *$ & $-0.231 * * *$ & $-1.113^{* * *}$ \\
\hline & [0.131] & [0.048] & [0.166] & [0.137] & [0.048] & [0.169] \\
\hline \multirow[t]{2}{*}{ Working Age } & 0.431 & 0.122 & 0.552 & 0.242 & 0.065 & 0.308 \\
\hline & {$[0.484]$} & [0.139] & {$[0.622]$} & [0.491] & {$[0.132]$} & {$[0.621]$} \\
\hline \multirow[t]{2}{*}{ Senior } & 0.25 & 0.075 & 0.324 & -0.094 & -0.02 & -0.115 \\
\hline & {$[0.528]$} & {$[0.156]$} & {$[0.683]$} & [0.509] & {$[0.138]$} & {$[0.646]$} \\
\hline \multirow[t]{2}{*}{ Male } & -0.547 & -0.153 & -0.699 & -0.587 & -0.154 & -0.74 \\
\hline & {$[0.568]$} & {$[0.160]$} & {$[0.725]$} & {$[0.587]$} & {$[0.156]$} & [0.739] \\
\hline \multirow[t]{2}{*}{ White } & $0.948 * * *$ & $0.267 * * *$ & $1.215^{* * *}$ & $0.973 * * *$ & $0.255^{* * *}$ & $1.228 * * *$ \\
\hline & [0.295] & [0.091] & [0.377] & [0.303] & [0.088] & {$[0.380]$} \\
\hline \multirow[t]{2}{*}{ Greater Tax } & 0.005 & 0.001 & 0.006 & 0.005 & 0.001 & 0.006 \\
\hline & [0.007] & [0.002] & [0.009] & {$[0.007]$} & [0.002] & [0.009] \\
\hline \multirow[t]{2}{*}{ Lower Tax } & $0.015^{* *}$ & $0.004^{* *}$ & $0.019 * *$ & $0.015^{* *}$ & $0.004 * *$ & $0.019 * *$ \\
\hline & {$[0.006]$} & {$[0.002]$} & [0.008] & [0.006] & [0.002] & [0.008] \\
\hline \multirow[t]{2}{*}{ Spatial Effect } & $0.224 * * *$ & $0.224 * * *$ & $0.224^{* * *}$ & $0.211^{* * *}$ & $0.211^{* * *}$ & $0.211^{* * *}$ \\
\hline & {$[0.027]$} & {$[0.027]$} & [0.027] & [0.028] & {$[0.028]$} & [0.028] \\
\hline Fixed Effects & \multicolumn{3}{|c|}{ County } & \multicolumn{3}{|c|}{ County } \\
\hline Year Dummies & \multicolumn{3}{|c|}{ Yes } & \multicolumn{3}{|c|}{ Yes } \\
\hline \multicolumn{6}{|l|}{ Only Sales Tax } & Yes \\
\hline $\mathbf{R}^{2}$ & \multicolumn{3}{|c|}{0.0878} & \multicolumn{3}{|c|}{0.0885} \\
\hline Observations & \multicolumn{3}{|c|}{18108} & \multicolumn{3}{|c|}{17244} \\
\hline
\end{tabular}

Robust standard errors in brackets

* significant at $10 \%$;* significant at 5\%; *** significant at $1 \%$ 
Table 7: Regression Results, Combined Rate, Employment, Total (with Spatial Lag Model)

\begin{tabular}{|c|c|c|c|c|c|c|}
\hline \multirow{2}{*}{$\begin{array}{c}\text { Total } \\
\text { Employment }\end{array}$} & \multicolumn{3}{|c|}{ (1) } & \multicolumn{3}{|c|}{ (2) } \\
\hline & Direct & Indirect & Total & Direct & Indirect & Total \\
\hline \multirow[t]{2}{*}{ Combined Rate } & $-0.472^{*}$ & $-0.072 *$ & $-0.545^{*}$ & $-0.492 *$ & $-0.067 *$ & $-0.559 *$ \\
\hline & {$[0.267]$} & {$[0.043]$} & {$[0.306]$} & {$[0.271]$} & {$[0.040]$} & {$[0.306]$} \\
\hline \multirow[t]{2}{*}{ Corporate } & -0.019 & -0.003 & -0.021 & -0.052 & -0.007 & -0.059 \\
\hline & [0.109] & {$[0.017]$} & {$[0.126]$} & [0.109] & {$[0.016]$} & {$[0.124]$} \\
\hline \multirow[t]{2}{*}{ Individual } & $-0.455^{* *}$ & $-0.071^{*}$ & $-0.526^{* *}$ & 0.016 & 0.001 & 0.017 \\
\hline & {$[0.211]$} & {$[0.038]$} & {$[0.246]$} & {$[0.228]$} & {$[0.032]$} & {$[0.260]$} \\
\hline \multirow[t]{2}{*}{ Personal } & $0.200 * * *$ & $0.031 * * *$ & $0.231 * * *$ & $0.209^{* * *}$ & $0.029 * * *$ & $0.237 * * *$ \\
\hline & {$[0.025]$} & {$[0.007]$} & {$[0.028]$} & {$[0.026]$} & {$[0.007]$} & {$[0.029]$} \\
\hline \multirow[t]{2}{*}{ Labor } & $0.525 * * *$ & $0.081^{* * *}$ & $0.607 * * *$ & $0.507 * * *$ & $0.070 * * *$ & $0.577 * * *$ \\
\hline & {$[0.042]$} & {$[0.018]$} & {$[0.050]$} & {$[0.043]$} & {$[0.018]$} & {$[0.051]$} \\
\hline \multirow[t]{2}{*}{ Unemployment } & $-1.461 * * *$ & $-0.226 * * *$ & $-1.687 * * *$ & $-1.463 * * *$ & $-0.201 * * *$ & $-1.664 * * *$ \\
\hline & {$[0.112]$} & [0.047] & [0.128] & [0.117] & [0.048] & {$[0.131]$} \\
\hline \multirow[t]{2}{*}{ Working Age } & $0.763 * *$ & $0.117 * *$ & $0.880 * *$ & $1.044 * * *$ & $0.142 * *$ & $1.186^{* * * *}$ \\
\hline & {$[0.337]$} & {$[0.056]$} & {$[0.387]$} & {$[0.348]$} & {$[0.057]$} & [0.393] \\
\hline \multirow{2}{*}{ Senior } & 0.212 & 0.033 & 0.245 & 0.34 & 0.047 & 0.387 \\
\hline & {$[0.378]$} & {$[0.062]$} & {$[0.439]$} & {$[0.407]$} & {$[0.061]$} & {$[0.465]$} \\
\hline \multirow[t]{2}{*}{ Male } & -0.254 & -0.04 & -0.294 & -0.342 & -0.048 & -0.389 \\
\hline & {$[0.436]$} & {$[0.072]$} & {$[0.506]$} & {$[0.449]$} & {$[0.068]$} & {$[0.514]$} \\
\hline \multirow[t]{2}{*}{ White } & 0.133 & 0.021 & 0.155 & 0.207 & 0.029 & 0.237 \\
\hline & {$[0.206]$} & {$[0.033]$} & {$[0.238]$} & {$[0.222]$} & {$[0.032]$} & {$[0.253]$} \\
\hline \multirow[t]{2}{*}{ Greater Tax } & -0.003 & -0.001 & -0.004 & -0.003 & -0.001 & -0.004 \\
\hline & {$[0.004]$} & {$[0.001]$} & {$[0.005]$} & {$[0.004]$} & {$[0.001]$} & {$[0.005]$} \\
\hline \multirow[t]{2}{*}{ Lower Tax } & $0.012 * * *$ & $0.002 * * *$ & $0.014 * * *$ & $0.012 * * *$ & $0.002 * *$ & $0.014 * * *$ \\
\hline & {$[0.004]$} & {$[0.001]$} & {$[0.005]$} & {$[0.004]$} & {$[0.001]$} & {$[0.005]$} \\
\hline \multirow[t]{2}{*}{ Spatial Effect } & $0.135 * * *$ & $0.135 * * *$ & $0.135 * * *$ & $0.122 * * *$ & $0.122 * * *$ & $0.122 * * *$ \\
\hline & {$[0.024]$} & {$[0.024]$} & {$[0.024]$} & {$[0.025]$} & {$[0.025]$} & {$[0.025]$} \\
\hline Fixed Effects & \multicolumn{3}{|c|}{ County } & \multicolumn{3}{|c|}{ County } \\
\hline Year Dummies & \multicolumn{3}{|c|}{ Yes } & \multicolumn{3}{|c|}{ Yes } \\
\hline $\begin{array}{c}\text { Only Sales Tax } \\
>0\end{array}$ & \multicolumn{3}{|c|}{ No } & \multicolumn{3}{|c|}{ Yes } \\
\hline $\mathbf{R}^{2}$ & \multicolumn{3}{|c|}{0.227} & \multicolumn{3}{|c|}{0.223} \\
\hline Observations & \multicolumn{3}{|c|}{18648} & \multicolumn{3}{|c|}{17658} \\
\hline
\end{tabular}

Robust standard errors in brackets

$*$ significant at $10 \%$; * significant at $5 \%$; *** significant at $1 \%$ 
Table 8: Regression Results, Combined Rate, Employment, Manufacturing (with Spatial Lag Model)

\begin{tabular}{|c|c|c|c|c|c|c|}
\hline \multirow{2}{*}{$\begin{array}{c}\text { Manufacturing } \\
\text { Employment }\end{array}$} & \multicolumn{3}{|c|}{ (1) } & \multicolumn{3}{|c|}{ (2) } \\
\hline & Direct & Indirect & Total & Direct & Indirect & Total \\
\hline \multirow[t]{2}{*}{ Combined Rate } & -0.495 & -0.157 & -0.652 & -0.545 & -0.18 & -0.725 \\
\hline & {$[0.722]$} & {$[0.237]$} & {$[0.955]$} & {$[0.728]$} & {$[0.249]$} & {$[0.972]$} \\
\hline \multirow[t]{2}{*}{ Corporate } & 0.249 & 0.083 & 0.333 & 0.275 & 0.095 & 0.371 \\
\hline & {$[0.272]$} & [0.095] & {$[0.365]$} & {$[0.273]$} & [0.099] & {$[0.370]$} \\
\hline \multirow[t]{2}{*}{ Individual } & -0.292 & -0.101 & -0.392 & -0.239 & -0.088 & -0.327 \\
\hline & {$[0.584]$} & [0.195] & {$[0.776]$} & {$[0.625]$} & [0.217] & [0.839] \\
\hline \multirow[t]{2}{*}{ Personal } & $0.188^{* *}$ & $0.061 * *$ & $0.249^{* *}$ & $0.167 * *$ & $0.057 *$ & $0.224 * *$ \\
\hline & [0.081] & [0.029] & [0.108] & [0.083] & {$[0.031]$} & [0.112] \\
\hline \multirow[t]{2}{*}{ Labor } & $0.775^{* * *} *$ & $0.253^{* * *}$ & $1.027 * * *$ & $0.778 * * *$ & $0.264 * * *$ & $1.042 * * *$ \\
\hline & [0.124] & [0.059] & {$[0.172]$} & [0.126] & [0.061] & {$[0.175]$} \\
\hline \multirow[t]{2}{*}{ Unemployment } & $-2.243 * * *$ & $-0.731 * * *$ & $-2.974 * * *$ & $-2.134 * * *$ & $-0.723 * * *$ & $-2.857 * * *$ \\
\hline & [0.268] & [0.148] & [0.377] & {$[0.275]$} & [0.149] & [0.387] \\
\hline \multirow[t]{2}{*}{ Working Age } & $2.192 * *$ & $0.707^{* *}$ & $2.900^{* *}$ & $2.388^{* *}$ & $0.801 * *$ & $3.189^{* *}$ \\
\hline & {$[0.948]$} & [0.316] & [1.246] & [0.996] & {$[0.345]$} & [1.319] \\
\hline \multirow[t]{2}{*}{ Senior } & 1.1 & 0.359 & 1.459 & 1.119 & 0.379 & 1.498 \\
\hline & [1.078] & [0.364] & [1.436] & [1.115] & [0.390] & [1.499] \\
\hline \multirow[t]{2}{*}{ Male } & -2.154 & -0.709 & -2.863 & -2.179 & -0.747 & -2.926 \\
\hline & [1.515] & {$[0.510]$} & [2.010] & {$[1.558]$} & [0.547] & [2.089] \\
\hline \multirow[t]{2}{*}{ White } & $1.125^{* *}$ & $0.364^{* *}$ & $1.489^{* *}$ & $1.311^{* * *}$ & $0.442 * * *$ & $1.753^{* * *}$ \\
\hline & {$[0.468]$} & {$[0.161]$} & {$[0.618]$} & [0.464] & [0.169] & [0.618] \\
\hline \multirow[t]{2}{*}{ Greater Tax } & -0.009 & -0.003 & -0.012 & -0.009 & -0.003 & -0.012 \\
\hline & {$[0.015]$} & {$[0.005]$} & {$[0.019]$} & {$[0.015]$} & {$[0.005]$} & {$[0.020]$} \\
\hline \multirow[t]{2}{*}{ Lower Tax } & 0.007 & 0.002 & 0.01 & 0.007 & 0.002 & 0.01 \\
\hline & {$[0.014]$} & {$[0.004]$} & {$[0.018]$} & {$[0.014]$} & {$[0.005]$} & {$[0.018]$} \\
\hline \multirow[t]{2}{*}{ Spatial Effect } & $0.250 * * *$ & $0.250^{* * * *}$ & $0.250 * * *$ & $0.258^{* * * *}$ & $0.258^{* * *}$ & $0.258^{* * *}$ \\
\hline & [0.029] & [0.029] & [0.029] & [0.029] & [0.029] & [0.029] \\
\hline Fixed Effects & \multicolumn{3}{|c|}{ County } & \multicolumn{3}{|c|}{ County } \\
\hline Year Dummies & \multicolumn{3}{|c|}{ Yes } & \multicolumn{3}{|c|}{ Yes } \\
\hline $\begin{array}{c}\text { Only Sales Tax } \\
>0\end{array}$ & \multicolumn{5}{|c|}{ Only Sales Tax } & Yes \\
\hline $\mathbf{R}^{2}$ & \multicolumn{3}{|c|}{0.0138} & \multicolumn{3}{|c|}{0.0193} \\
\hline Observations & \multicolumn{3}{|c|}{11592} & \multicolumn{3}{|c|}{11061} \\
\hline
\end{tabular}

Robust standard errors in brackets

$*$ significant at $10 \%$; ** significant at 5\%; *** significant at $1 \%$ 
Table 9: Regression Results, Combined Rate, Employment, Retail Trade (with Spatial Lag Model)

\begin{tabular}{|c|c|c|c|c|c|c|}
\hline \multirow{2}{*}{$\begin{array}{c}\text { Retail } \\
\text { Employment }\end{array}$} & \multicolumn{3}{|c|}{ (1) } & \multicolumn{3}{|c|}{ (2) } \\
\hline & Direct & Indirect & Total & Direct & Indirect & Total \\
\hline \multirow[t]{2}{*}{ Combined Rate } & -0.052 & -0.006 & -0.058 & -0.126 & -0.014 & -0.139 \\
\hline & {$[0.330]$} & {$[0.043]$} & {$[0.372]$} & [0.334] & {$[0.041]$} & {$[0.373]$} \\
\hline \multirow{2}{*}{ Corporate } & -0.008 & 0 & -0.008 & -0.041 & -0.004 & -0.044 \\
\hline & {$[0.137]$} & {$[0.018]$} & {$[0.154]$} & {$[0.137]$} & {$[0.017]$} & {$[0.153]$} \\
\hline \multirow[t]{2}{*}{ Individual } & -0.198 & -0.026 & -0.224 & 0.352 & 0.04 & 0.392 \\
\hline & {$[0.247]$} & {$[0.033]$} & {$[0.278]$} & {$[0.255]$} & {$[0.031]$} & {$[0.284]$} \\
\hline \multirow[t]{2}{*}{ Personal } & $0.212 * * *$ & $0.027 * * *$ & $0.239 * * *$ & $0.214^{* * *}$ & $0.025^{* * *}$ & $0.239^{* * * *}$ \\
\hline & [0.029] & [0.008] & [0.033] & [0.030] & [0.008] & {$[0.034]$} \\
\hline \multirow[t]{2}{*}{ Labor } & $0.146^{* * *}$ & $0.018^{* *}$ & $0.164 * * *$ & $0.143 * * *$ & $0.016^{* *}$ & $0.160 * * *$ \\
\hline & [0.054] & {$[0.008]$} & {$[0.060]$} & [0.055] & {$[0.008]$} & {$[0.061]$} \\
\hline \multirow[t]{2}{*}{ Unemployment } & $-0.676^{* * * *}$ & $-0.085^{* * *}$ & $-0.762 * * *$ & $-0.689 * * *$ & $-0.080 * * *$ & $-0.768 * * *$ \\
\hline & [0.108] & {$[0.026]$} & {$[0.122]$} & [0.112] & {$[0.026]$} & {$[0.124]$} \\
\hline \multirow[t]{2}{*}{ Working Age } & 0.407 & 0.052 & 0.459 & 0.379 & 0.045 & 0.424 \\
\hline & {$[0.409]$} & {$[0.055]$} & {$[0.461]$} & {$[0.435]$} & {$[0.055]$} & {$[0.485]$} \\
\hline \multirow[t]{2}{*}{ Senior } & $0.729 *$ & 0.095 & $0.823^{*}$ & 0.651 & 0.079 & 0.73 \\
\hline & {$[0.426]$} & {$[0.066]$} & {$[0.487]$} & {$[0.442]$} & {$[0.063]$} & {$[0.500]$} \\
\hline \multirow[t]{2}{*}{ Male } & $-1.220 * *$ & $-0.153 * *$ & $-1.374 * *$ & $-1.306^{* *}$ & $-0.151^{*}$ & $-1.456^{* *}$ \\
\hline & {$[0.526]$} & {$[0.076]$} & {$[0.590]$} & {$[0.548]$} & {$[0.077]$} & {$[0.610]$} \\
\hline \multirow[t]{2}{*}{ White } & 0.244 & 0.031 & 0.276 & 0.24 & 0.028 & 0.268 \\
\hline & {$[0.242]$} & [0.033] & {$[0.273]$} & {$[0.251]$} & {$[0.031]$} & {$[0.280]$} \\
\hline \multirow[t]{2}{*}{ Greater Tax } & 0 & 0 & 0.001 & 0 & 0 & 0 \\
\hline & {$[0.005]$} & {$[0.001]$} & {$[0.006]$} & {$[0.005]$} & {$[0.001]$} & {$[0.005]$} \\
\hline \multirow[t]{2}{*}{ Lower Tax } & 0.006 & 0.001 & 0.007 & 0.007 & 0.001 & 0.007 \\
\hline & {$[0.005]$} & {$[0.001]$} & {$[0.005]$} & {$[0.005]$} & {$[0.001]$} & {$[0.005]$} \\
\hline \multirow[t]{2}{*}{ Spatial Effect } & $0.114 * * *$ & $0.114 * * *$ & $0.114 * * *$ & $0.105 * * *$ & $0.105^{* * *}$ & $0.105^{* * *}$ \\
\hline & {$[0.025]$} & {$[0.025]$} & {$[0.025]$} & {$[0.026]$} & {$[0.026]$} & {$[0.026]$} \\
\hline Fixed Effects & \multicolumn{3}{|c|}{ County } & \multicolumn{3}{|c|}{ County } \\
\hline Year Dummies & \multicolumn{3}{|c|}{ Yes } & \multicolumn{3}{|c|}{ Yes } \\
\hline \multicolumn{5}{|l|}{ Only Sales Tax } & \multicolumn{2}{|l|}{ Yes } \\
\hline $\mathbf{R}^{2}$ & \multicolumn{3}{|c|}{0.144} & \multicolumn{3}{|c|}{0.1462} \\
\hline Observations & \multicolumn{3}{|c|}{17181} & \multicolumn{3}{|c|}{16371} \\
\hline
\end{tabular}

Robust standard errors in brackets

$*$ significant at $10 \%$;* significant at $5 \%$; *** significant at $1 \%$ 
Table 10: Regression Results, Combined Rate, Establishments, Total (with Spatial Lag Model)

\begin{tabular}{|c|c|c|c|c|c|c|}
\hline \multirow{2}{*}{$\begin{array}{c}\text { Total } \\
\text { Establishments }\end{array}$} & \multicolumn{3}{|c|}{ (1) } & \multicolumn{3}{|c|}{ (2) } \\
\hline & Direct & Indirect & Total & Direct & Indirect & Total \\
\hline \multirow[t]{2}{*}{ Combined Rate } & -0.081 & -0.031 & -0.113 & -0.097 & -0.035 & -0.133 \\
\hline & {$[0.145]$} & {$[0.057]$} & {$[0.202]$} & {$[0.148]$} & {$[0.055]$} & {$[0.202]$} \\
\hline \multirow[t]{2}{*}{ Corporate } & -0.056 & -0.022 & -0.078 & -0.06 & -0.023 & -0.083 \\
\hline & {$[0.069]$} & {$[0.028]$} & [0.097] & {$[0.068]$} & {$[0.026]$} & {$[0.093]$} \\
\hline \multirow[t]{2}{*}{ Individual } & -0.075 & -0.031 & -0.106 & -0.019 & -0.008 & -0.027 \\
\hline & {$[0.140]$} & [0.057] & [0.196] & [0.117] & {$[0.044]$} & {$[0.161]$} \\
\hline \multirow[t]{2}{*}{ Personal } & $0.124 * * *$ & $0.049^{* * *}$ & $0.173^{* * * *}$ & $0.127 * * *$ & $0.047 * * *$ & $0.175^{* * *}$ \\
\hline & [0.018] & [0.009] & [0.024] & [0.018] & [0.009] & {$[0.025]$} \\
\hline \multirow[t]{2}{*}{ Labor } & $0.172 * * *$ & $0.068 * * *$ & $0.240 * * *$ & $0.170 * * *$ & $0.064 * * *$ & $0.234 * * *$ \\
\hline & [0.027] & [0.015] & [0.039] & [0.028] & [0.015] & [0.040] \\
\hline \multirow[t]{2}{*}{ Unemployment } & $-0.386 * * *$ & $-0.152 * * *$ & $-0.538 * * *$ & $-0.381 * * *$ & $-0.142 * * *$ & $-0.523 * * *$ \\
\hline & [0.054] & [0.029] & {$[0.076]$} & [0.057] & [0.028] & [0.079] \\
\hline \multirow[t]{2}{*}{ Working Age } & $0.788 * * *$ & $0.311 * * *$ & $1.099 * * *$ & $0.921 * * *$ & $0.345^{* * * *}$ & $1.266^{* * *}$ \\
\hline & [0.211] & [0.093] & [0.296] & [0.239] & [0.103] & [0.333] \\
\hline \multirow[t]{2}{*}{ Senior } & $0.959 * * *$ & $0.381 * * *$ & $1.340 * * *$ & $0.970 * * *$ & $0.365^{* * *}$ & $1.335^{* * *}$ \\
\hline & {$[0.220]$} & [0.109] & [0.319] & [0.244] & [0.113] & [0.348] \\
\hline \multirow[t]{2}{*}{ Male } & $-0.887 * * *$ & $-0.351 * * *$ & $-1.238 * * *$ & $-1.039 * * *$ & $-0.389 * * *$ & $-1.428^{* * * *}$ \\
\hline & [0.267] & [0.116] & [0.374] & [0.280] & [0.120] & [0.390] \\
\hline \multirow[t]{2}{*}{ White } & 0.1 & 0.04 & 0.14 & 0.201 & 0.075 & 0.277 \\
\hline & {$[0.134]$} & {$[0.054]$} & {$[0.187]$} & {$[0.132]$} & {$[0.051]$} & {$[0.181]$} \\
\hline \multirow[t]{2}{*}{ Greater Tax } & -0.003 & -0.001 & -0.004 & -0.003 & -0.001 & -0.004 \\
\hline & {$[0.002]$} & {$[0.001]$} & {$[0.003]$} & {$[0.002]$} & {$[0.001]$} & {$[0.003]$} \\
\hline \multirow[t]{2}{*}{ Lower Tax } & 0.001 & 0 & 0.001 & 0.001 & 0 & 0.001 \\
\hline & {$[0.002]$} & {$[0.001]$} & [0.003] & [0.002] & {$[0.001]$} & [0.003] \\
\hline \multirow[t]{2}{*}{ Spatial Effect } & $0.289 * * *$ & $0.289 * * *$ & $0.289 * * *$ & $0.278^{* * *}$ & $0.278^{* * *}$ & $0.278^{* * *}$ \\
\hline & {$[0.028]$} & [0.028] & {$[0.028]$} & [0.028] & [0.028] & {$[0.028]$} \\
\hline Fixed Effects & \multicolumn{3}{|c|}{ County } & \multicolumn{3}{|c|}{ County } \\
\hline Year Dummies & \multicolumn{3}{|c|}{ Yes } & \multicolumn{3}{|c|}{ Yes } \\
\hline $\begin{array}{c}\text { Only Sales Tax } \\
>0\end{array}$ & \multicolumn{3}{|c|}{ No } & \multicolumn{3}{|c|}{ Yes } \\
\hline $\mathbf{R}^{2}$ & \multicolumn{3}{|c|}{0.4437} & \multicolumn{3}{|c|}{0.4271} \\
\hline Observations & \multicolumn{3}{|c|}{19296} & \multicolumn{3}{|c|}{18225} \\
\hline
\end{tabular}

Robust standard errors in brackets

$*$ significant at $10 \%$; * significant at $5 \%$; *** significant at $1 \%$ 
Table 11: Regression Results, Combined Rate, Establishments, Manufacturing (with Spatial Lag Model)

\begin{tabular}{|c|c|c|c|c|c|c|}
\hline \multirow{2}{*}{$\begin{array}{l}\text { Manufacturing } \\
\text { Establishments }\end{array}$} & \multicolumn{3}{|c|}{ (1) } & \multicolumn{3}{|c|}{ (2) } \\
\hline & Direct & Indirect & Total & Direct & Indirect & Total \\
\hline \multirow[t]{2}{*}{ Combined Rate } & 0.066 & 0.015 & 0.081 & 0.132 & 0.026 & 0.158 \\
\hline & [0.472] & [0.101] & {$[0.571]$} & {$[0.471]$} & {$[0.092]$} & {$[0.562]$} \\
\hline \multirow[t]{2}{*}{ Corporate } & 0.162 & 0.035 & 0.197 & 0.235 & 0.046 & 0.281 \\
\hline & {$[0.263]$} & {$[0.058]$} & {$[0.320]$} & {$[0.263]$} & [0.054] & {$[0.316]$} \\
\hline \multirow[t]{2}{*}{ Individual } & 0.079 & 0.018 & 0.096 & $-0.660^{*}$ & $-0.126^{*}$ & $-0.786^{*}$ \\
\hline & [0.532] & [0.111] & [0.642] & [0.369] & {$[0.074]$} & {$[0.440]$} \\
\hline \multirow[t]{2}{*}{ Personal } & $0.115^{* *}$ & $0.024 * *$ & $0.139 * *$ & $0.129 * * *$ & $0.025 * *$ & $0.154 * * *$ \\
\hline & [0.049] & [0.011] & [0.059] & [0.049] & [0.011] & [0.059] \\
\hline \multirow[t]{2}{*}{ Labor } & $0.220 * * *$ & $0.046^{* *}$ & $0.265 * * *$ & $0.198^{* *}$ & $0.038^{* *}$ & $0.235^{* *}$ \\
\hline & [0.079] & [0.018] & [0.095] & {$[0.078]$} & {$[0.016]$} & [0.093] \\
\hline \multirow[t]{2}{*}{ Unemployment } & $-0.795 * * *$ & $-0.165^{* * *}$ & $-0.960 * * *$ & $-0.770 * * *$ & $-0.147 * * *$ & $-0.916^{* * *}$ \\
\hline & [0.203] & [0.048] & {$[0.245]$} & [0.203] & [0.045] & {$[0.241]$} \\
\hline \multirow[t]{2}{*}{ Working Age } & $1.810^{* * *}$ & $0.374 * * *$ & $2.184 * * *$ & $1.973 * * *$ & $0.374 * * *$ & $2.348 * * *$ \\
\hline & [0.664] & {$[0.140]$} & [0.792] & [0.643] & [0.131] & {$[0.758]$} \\
\hline \multirow[t]{2}{*}{ Senior } & $2.014 * * *$ & $0.423 * *$ & $2.437 * * *$ & $1.755^{* *}$ & $0.338 * *$ & $2.094 * *$ \\
\hline & {$[0.721]$} & [0.174] & [0.883] & [0.694] & {$[0.155]$} & {$[0.838]$} \\
\hline \multirow[t]{2}{*}{ Male } & -1.339 & -0.278 & -1.617 & $-1.693^{*}$ & $-0.321^{*}$ & $-2.014^{*}$ \\
\hline & [1.007] & {$[0.213]$} & [1.214] & {$[0.928]$} & {$[0.183]$} & [1.101] \\
\hline \multirow[t]{2}{*}{ White } & 0.506 & 0.105 & 0.611 & $0.657^{*}$ & $0.126^{*}$ & $0.783^{*}$ \\
\hline & {$[0.431]$} & [0.092] & {$[0.521]$} & {$[0.357]$} & {$[0.072]$} & {$[0.426]$} \\
\hline \multirow[t]{2}{*}{ Greater Tax } & -0.002 & -0.001 & -0.003 & -0.002 & -0.001 & -0.003 \\
\hline & [0.009] & {$[0.002]$} & [0.011] & [0.009] & {$[0.002]$} & [0.011] \\
\hline \multirow[t]{2}{*}{ Lower Tax } & 0.003 & 0 & 0.003 & 0.002 & 0 & 0.003 \\
\hline & {$[0.008]$} & {$[0.002]$} & {$[0.010]$} & {$[0.008]$} & [0.002] & {$[0.010]$} \\
\hline \multirow[t]{2}{*}{ Spatial Effect } & $0.175^{* * *}$ & $0.175^{* * *}$ & $0.175^{* * * *}$ & $0.162 * * *$ & $0.162 * * *$ & $0.162 * * *$ \\
\hline & {$[0.021]$} & {$[0.021]$} & {$[0.021]$} & [0.022] & [0.022] & {$[0.022]$} \\
\hline Fixed Effects & \multicolumn{3}{|c|}{ County } & \multicolumn{3}{|c|}{ County } \\
\hline Year Dummies & \multicolumn{3}{|c|}{ Yes } & \multicolumn{3}{|c|}{ Yes } \\
\hline $\begin{array}{c}\text { Only Sales Tax } \\
>0\end{array}$ & \multicolumn{3}{|c|}{ No } & \multicolumn{3}{|c|}{ Yes } \\
\hline $\mathbf{R}^{2}$ & \multicolumn{3}{|c|}{0.1572} & \multicolumn{3}{|c|}{0.1464} \\
\hline Observations & \multicolumn{3}{|c|}{18684} & \multicolumn{3}{|c|}{17703} \\
\hline
\end{tabular}

Robust standard errors in brackets

$*$ significant at $10 \%$; ** significant at $5 \%$; *** significant at $1 \%$ 
Table 12: Regression Results, Combined Rate, Establishments, Retail Trade (with Spatial Lag Model)

\begin{tabular}{|c|c|c|c|c|c|c|}
\hline \multirow{2}{*}{$\begin{array}{c}\text { Retail } \\
\text { Establishments }\end{array}$} & \multicolumn{3}{|c|}{ (1) } & \multicolumn{3}{|c|}{ (2) } \\
\hline & Direct & Indirect & Total & Direct & Indirect & Total \\
\hline \multirow[t]{2}{*}{ Combined Rate } & $-0.671 * * *$ & -0.024 & $-0.695^{* * *}$ & $-0.746^{* * *}$ & -0.019 & $-0.765 * * *$ \\
\hline & {$[0.241]$} & {$[0.021]$} & [0.249] & [0.244] & {$[0.023]$} & {$[0.250]$} \\
\hline \multirow[t]{2}{*}{ Corporate } & -0.035 & -0.001 & -0.036 & -0.042 & -0.001 & -0.042 \\
\hline & [0.109] & {$[0.005]$} & {$[0.113]$} & [0.109] & {$[0.004]$} & [0.112] \\
\hline \multirow[t]{2}{*}{ Individual } & 0.076 & 0.002 & 0.078 & $0.335^{*}$ & 0.008 & $0.344^{*}$ \\
\hline & {$[0.220]$} & [0.009] & {$[0.228]$} & {$[0.177]$} & {$[0.010]$} & {$[0.181]$} \\
\hline \multirow[t]{2}{*}{ Personal } & $0.076^{* * *}$ & 0.003 & $0.079 * * *$ & $0.088^{* * * *}$ & 0.002 & $0.090^{* * *}$ \\
\hline & [0.028] & {$[0.002]$} & [0.029] & {$[0.029]$} & {$[0.003]$} & [0.029] \\
\hline \multirow[t]{2}{*}{ Labor } & $0.147 * * *$ & 0.005 & $0.152 * * *$ & $0.132 * * *$ & 0.004 & $0.136^{* * * *}$ \\
\hline & [0.042] & {$[0.004]$} & [0.044] & [0.042] & {$[0.004]$} & [0.043] \\
\hline \multirow[t]{2}{*}{ Unemployment } & 0.099 & 0.004 & 0.103 & 0.101 & 0.003 & 0.103 \\
\hline & [0.089] & {$[0.005]$} & {$[0.093]$} & {$[0.092]$} & {$[0.004]$} & [0.095] \\
\hline \multirow[t]{2}{*}{ Working Age } & $0.801 * *$ & 0.029 & $0.831 * *$ & $0.869 * *$ & 0.024 & $0.893 * *$ \\
\hline & {$[0.351]$} & {$[0.026]$} & {$[0.365]$} & [0.359] & {$[0.028]$} & {$[0.371]$} \\
\hline \multirow[t]{2}{*}{ Senior } & $1.014 * * *$ & 0.038 & $1.052 * * *$ & $0.929 * * *$ & 0.027 & $0.956^{* * *}$ \\
\hline & {$[0.336]$} & {$[0.033]$} & {$[0.355]$} & {$[0.326]$} & {$[0.030]$} & [0.342] \\
\hline \multirow[t]{2}{*}{ Male } & $-0.843^{* *}$ & -0.029 & $-0.872 * *$ & $-1.134 * *$ & -0.03 & $-1.164 * *$ \\
\hline & {$[0.421]$} & {$[0.027]$} & {$[0.435]$} & {$[0.449]$} & {$[0.035]$} & {$[0.461]$} \\
\hline \multirow[t]{2}{*}{ White } & -0.159 & -0.005 & -0.165 & -0.155 & -0.004 & -0.159 \\
\hline & [0.193] & {$[0.008]$} & [0.199] & {$[0.204]$} & {$[0.008]$} & [0.209] \\
\hline \multirow[t]{2}{*}{ Greater Tax } & -0.001 & 0 & -0.001 & -0.001 & 0 & -0.001 \\
\hline & {$[0.004]$} & {$[0.000]$} & {$[0.004]$} & [0.004] & {$[0.000]$} & {$[0.004]$} \\
\hline \multirow[t]{2}{*}{ Lower Tax } & $0.009 * *$ & 0 & $0.009 * *$ & $0.009 * *$ & 0 & $0.009^{* *}$ \\
\hline & {$[0.004]$} & {$[0.000]$} & {$[0.004]$} & [0.004] & {$[0.000]$} & {$[0.004]$} \\
\hline \multirow[t]{2}{*}{ Spatial Effect } & 0.035 & 0.035 & 0.035 & 0.026 & 0.026 & 0.026 \\
\hline & {$[0.022]$} & {$[0.022]$} & {$[0.022]$} & {$[0.024]$} & {$[0.024]$} & {$[0.024]$} \\
\hline Fixed Effects & \multicolumn{3}{|c|}{ County } & \multicolumn{3}{|c|}{ County } \\
\hline Year Dummies & \multicolumn{3}{|c|}{ Yes } & \multicolumn{3}{|c|}{ Yes } \\
\hline \multicolumn{4}{|l|}{ Only Sales Tax } & \multicolumn{3}{|c|}{ Yes } \\
\hline $\mathbf{R}^{2}$ & \multicolumn{3}{|c|}{0.1559} & \multicolumn{3}{|c|}{0.1244} \\
\hline Observations & \multicolumn{3}{|c|}{19251} & \multicolumn{3}{|c|}{18180} \\
\hline
\end{tabular}

Robust standard errors in brackets

* significant at $10 \%$;* significant at $5 \%$; *** significant at $1 \%$ 
Table 13: Regression Results, Combined Rate, Small Establishments, Total (with Spatial Lag Model)

\begin{tabular}{|c|c|c|c|c|c|c|}
\hline \multirow{2}{*}{$\begin{array}{c}\text { Total Small } \\
\text { Establishments }\end{array}$} & \multicolumn{3}{|c|}{ (1) } & \multicolumn{3}{|c|}{ (2) } \\
\hline & Direct & Indirect & Total & Direct & Indirect & Total \\
\hline \multirow[t]{2}{*}{ Combined Rate } & $-0.706^{* *}$ & $-0.195^{* *}$ & $-0.902^{* *}$ & $-0.269^{*}$ & $-0.088^{*}$ & $-0.357^{*}$ \\
\hline & {$[0.326]$} & [0.095] & [0.416] & [0.147] & [0.049] & [0.195] \\
\hline \multirow[t]{2}{*}{ Corporate } & -0.04 & -0.011 & -0.052 & -0.028 & -0.009 & -0.037 \\
\hline & [0.147] & {$[0.042]$} & [0.188] & {$[0.064]$} & [0.021] & {$[0.085]$} \\
\hline \multirow[t]{2}{*}{ Individual } & $-0.848^{* * *}$ & $-0.235^{* * *}$ & $-1.083^{* * *}$ & 0.066 & 0.021 & 0.087 \\
\hline & [0.284] & [0.088] & [0.364] & {$[0.117]$} & {$[0.039]$} & {$[0.155]$} \\
\hline \multirow[t]{2}{*}{ Personal } & $0.365^{* * *}$ & $0.101^{* * *}$ & $0.467^{* * *}$ & $0.105^{* * *}$ & $0.035^{* * *}$ & $0.140^{* * *}$ \\
\hline & [0.029] & [0.016] & [0.038] & [0.018] & [0.007] & [0.024] \\
\hline \multirow[t]{2}{*}{ Labor } & $0.633^{* * *}$ & $0.176^{* * *}$ & $0.810^{* * *}$ & $0.168^{* * *}$ & $0.055^{* * *}$ & $0.223^{* * *}$ \\
\hline & {$[0.056]$} & [0.032] & {$[0.077]$} & [0.026] & [0.012] & {$[0.035]$} \\
\hline \multirow[t]{2}{*}{ Unemployment } & $-1.713^{* * *}$ & $-0.475^{* * *}$ & $-2.189 * * *$ & $-0.370 * * *$ & $-0.122 * * *$ & $-0.492 * * *$ \\
\hline & {$[0.130]$} & [0.077] & [0.173] & [0.060] & [0.026] & [0.081] \\
\hline \multirow[t]{2}{*}{ Working Age } & $1.577^{* * *}$ & $0.435^{* * *}$ & $2.012^{* * *}$ & $0.814^{* * *}$ & $0.269 * * *$ & $1.084^{* * *}$ \\
\hline & {$[0.406]$} & [0.117] & {$[0.506]$} & [0.200] & {$[0.080]$} & {$[0.271]$} \\
\hline \multirow[t]{2}{*}{ Senior } & -0.025 & -0.007 & -0.032 & $0.985^{* * *}$ & $0.327^{* * *}$ & $1.312^{* * *}$ \\
\hline & {$[0.400]$} & [0.115] & [0.513] & [0.225] & [0.097] & [0.312] \\
\hline \multirow[t]{2}{*}{ Male } & -0.266 & -0.073 & -0.339 & $-1.164^{* * *}$ & $-0.384 * * *$ & $-1.547^{* * *}$ \\
\hline & [0.511] & {$[0.144]$} & {$[0.653]$} & [0.278] & [0.107] & [0.373] \\
\hline \multirow[t]{2}{*}{ White } & 0.316 & 0.089 & 0.405 & 0.112 & 0.037 & 0.15 \\
\hline & {$[0.255]$} & {$[0.074]$} & [0.327] & {$[0.140]$} & {$[0.047]$} & [0.187] \\
\hline \multirow[t]{2}{*}{ Greater Tax } & -0.001 & 0 & -0.001 & $-0.006 * * *$ & $-0.002 * *$ & $-0.008^{* * *}$ \\
\hline & [0.006] & {$[0.002]$} & [0.008] & [0.002] & [0.001] & [0.003] \\
\hline \multirow[t]{2}{*}{ Lower Tax } & $0.015^{* * *}$ & $0.004^{* * *}$ & $0.020^{* * *}$ & -0.002 & -0.001 & -0.002 \\
\hline & [0.005] & [0.002] & [0.007] & {$[0.002]$} & {$[0.001]$} & [0.003] \\
\hline \multirow[t]{2}{*}{ Spatial Effect } & $0.221^{* * *}$ & $0.221^{* * *}$ & $0.221^{* * *}$ & $0.253^{* * *}$ & $0.253^{* * *}$ & $0.253^{* * *}$ \\
\hline & [0.025] & {$[0.025]$} & {$[0.025]$} & {$[0.027]$} & {$[0.027]$} & {$[0.027]$} \\
\hline Fixed Effects & \multicolumn{3}{|c|}{ County } & \multicolumn{3}{|c|}{ County } \\
\hline Year Dummies & \multicolumn{3}{|c|}{ Yes } & \multicolumn{3}{|c|}{ Yes } \\
\hline \multicolumn{5}{|l|}{ Only Sales Tax } & \multicolumn{2}{|l|}{ Yes } \\
\hline $\mathbf{R}^{2}$ & \multicolumn{3}{|c|}{0.2493} & \multicolumn{3}{|c|}{0.4635} \\
\hline Observations & \multicolumn{3}{|c|}{18846} & \multicolumn{3}{|c|}{18225} \\
\hline
\end{tabular}

Robust standard errors in brackets

$*$ significant at $10 \%$; ** significant at $5 \%$; *** significant at $1 \%$ 
Table 14: Regression Results, Combined Rate, Small Establishments, Manufacturing (with Spatial Lag Model)

\begin{tabular}{|c|c|c|c|c|c|c|}
\hline \multirow{2}{*}{$\begin{array}{c}\text { MFR Small } \\
\text { Establishments }\end{array}$} & \multicolumn{3}{|c|}{ (1) } & \multicolumn{3}{|c|}{$(2)$} \\
\hline & Direct & Indirect & Total & Direct & Indirect & Total \\
\hline \multirow[t]{2}{*}{ Combined Rate } & -0.32 & -0.063 & -0.382 & -0.111 & -0.02 & -0.131 \\
\hline & [0.597] & [0.121] & {$[0.716]$} & [0.596] & {$[0.113]$} & {$[0.708]$} \\
\hline \multirow[t]{2}{*}{ Corporate } & 0.108 & 0.023 & 0.131 & 0.167 & 0.033 & 0.2 \\
\hline & [0.249] & {$[0.052]$} & {$[0.301]$} & [0.249] & {$[0.050]$} & {$[0.297]$} \\
\hline \multirow[t]{2}{*}{ Individual } & 0.088 & 0.017 & 0.105 & -0.561 & -0.106 & -0.667 \\
\hline & [0.475] & [0.094] & {$[0.568]$} & [0.431] & {$[0.084]$} & {$[0.512]$} \\
\hline \multirow[t]{2}{*}{ Personal } & $0.158^{* * *}$ & $0.031^{* *}$ & $0.189^{* * *}$ & $0.180^{* * *}$ & $0.034^{* * *}$ & $0.214^{* * *}$ \\
\hline & {$[0.056]$} & {$[0.012]$} & [0.067] & [0.057] & [0.012] & [0.068] \\
\hline \multirow[t]{2}{*}{ Labor } & $0.162^{*}$ & $0.032 *$ & $0.195^{*}$ & 0.082 & 0.016 & 0.097 \\
\hline & [0.087] & [0.018] & [0.105] & [0.088] & {$[0.017]$} & [0.105] \\
\hline \multirow[t]{2}{*}{ Unemployment } & $-0.367^{*}$ & -0.073 & $-0.440^{*}$ & -0.313 & -0.059 & -0.371 \\
\hline & {$[0.211]$} & {$[0.044]$} & {$[0.254]$} & {$[0.210]$} & {$[0.042]$} & {$[0.250]$} \\
\hline \multirow[t]{2}{*}{ Working Age } & $2.126^{* * *}$ & $0.418^{* * *}$ & $2.545^{* * *}$ & $2.362^{* * *}$ & $0.439 * * *$ & $2.801^{* * *}$ \\
\hline & {$[0.726]$} & {$[0.143]$} & [0.857] & {$[0.762]$} & [0.149] & [0.895] \\
\hline \multirow[t]{2}{*}{ Senior } & $1.894^{* *}$ & $0.377^{* *}$ & $2.271^{* *}$ & $1.332^{*}$ & $0.250^{*}$ & $1.582^{*}$ \\
\hline & {$[0.772]$} & {$[0.166]$} & [0.929] & {$[0.754]$} & {$[0.149]$} & {$[0.898]$} \\
\hline \multirow{2}{*}{ Male } & $-2.099 *$ & $-0.419 *$ & $-2.519 *$ & $-2.735^{* *}$ & $-0.513^{* *}$ & $-3.249 * *$ \\
\hline & [1.153] & {$[0.241]$} & {$[1.385]$} & [1.100] & {$[0.224]$} & [1.309] \\
\hline \multirow[t]{2}{*}{ White } & $0.716^{*}$ & 0.142 & $0.858^{*}$ & $0.983^{* * *}$ & $0.184^{* *}$ & $1.167^{* * *}$ \\
\hline & {$[0.434]$} & {$[0.089]$} & {$[0.520]$} & {$[0.377]$} & {$[0.077]$} & [0.448] \\
\hline \multirow[t]{2}{*}{ Greater Tax } & -0.012 & -0.002 & -0.014 & -0.011 & -0.002 & -0.013 \\
\hline & {$[0.010]$} & {$[0.002]$} & {$[0.013]$} & [0.010] & {$[0.002]$} & {$[0.012]$} \\
\hline \multirow[t]{2}{*}{ Lower Tax } & -0.003 & -0.001 & -0.003 & -0.004 & -0.001 & -0.004 \\
\hline & {$[0.010]$} & {$[0.002]$} & {$[0.012]$} & [0.010] & {$[0.002]$} & [0.012] \\
\hline \multirow[t]{2}{*}{ Spatial Effect } & $0.168^{* * *}$ & $0.168^{* * *}$ & $0.168^{* * *}$ & $0.160 * * *$ & $0.160 * * *$ & $0.160 * * *$ \\
\hline & {$[0.020]$} & {$[0.020]$} & {$[0.020]$} & {$[0.021]$} & {$[0.021]$} & {$[0.021]$} \\
\hline Fixed Effects & \multicolumn{3}{|c|}{ County } & \multicolumn{3}{|c|}{ County } \\
\hline Year Dummies & \multicolumn{3}{|c|}{ Yes } & \multicolumn{3}{|c|}{ Yes } \\
\hline $\begin{array}{c}\text { Only Sales Tax } \\
>0\end{array}$ & \multicolumn{3}{|c|}{ No } & \multicolumn{3}{|c|}{ Yes } \\
\hline $\mathbf{R}^{2}$ & \multicolumn{3}{|c|}{0.1952} & \multicolumn{3}{|c|}{0.1706} \\
\hline Observations & \multicolumn{3}{|c|}{18567} & \multicolumn{3}{|c|}{17586} \\
\hline
\end{tabular}

Robust standard errors in brackets

* significant at $10 \%$; ** significant at $5 \%$; *** significant at $1 \%$ 
Table 15: Regression Results, Combined Rate, Small Establishments, Retail Trade (with Spatial Lag Model)

\begin{tabular}{|c|c|c|c|c|c|c|}
\hline \multirow{2}{*}{$\begin{array}{c}\text { Retail Small } \\
\text { Establishments }\end{array}$} & \multicolumn{3}{|c|}{ (1) } & \multicolumn{3}{|c|}{ (2) } \\
\hline & Direct & Indirect & Total & Direct & Indirect & Total \\
\hline \multirow[t]{2}{*}{ Combined Rate } & $-0.823^{* * *}$ & -0.018 & $-0.841^{* * *}$ & $-0.890 * * *$ & -0.02 & $-0.910^{* * *}$ \\
\hline & [0.240] & {$[0.023]$} & [0.243] & [0.240] & {$[0.026]$} & [0.244] \\
\hline \multirow[t]{2}{*}{ Corporate } & -0.092 & -0.002 & -0.094 & -0.094 & -0.002 & -0.096 \\
\hline & {$[0.110]$} & [0.004] & [0.113] & [0.109] & {$[0.004]$} & [0.111] \\
\hline \multirow[t]{2}{*}{ Individual } & 0.225 & 0.004 & 0.229 & $0.529 * * *$ & 0.012 & $0.541^{* * *}$ \\
\hline & {$[0.253]$} & [0.009] & {$[0.257]$} & [0.180] & {$[0.014]$} & [0.182] \\
\hline \multirow[t]{2}{*}{ Personal } & $0.061 *$ & 0.001 & $0.062^{*}$ & $0.070^{* *}$ & 0.002 & $0.071^{* *}$ \\
\hline & [0.033] & [0.002] & {$[0.033]$} & [0.034] & {$[0.002]$} & {$[0.035]$} \\
\hline \multirow[t]{2}{*}{ Labor } & $0.163^{* * *}$ & 0.004 & $0.166^{* * *}$ & $0.158^{* * *}$ & 0.004 & $0.162^{* * *}$ \\
\hline & {$[0.040]$} & {$[0.004]$} & {$[0.041]$} & [0.039] & [0.004] & {$[0.040]$} \\
\hline \multirow[t]{2}{*}{ Unemployment } & 0.133 & 0.003 & 0.136 & 0.127 & 0.003 & 0.13 \\
\hline & [0.094] & {$[0.004]$} & {$[0.096]$} & [0.098] & {$[0.005]$} & {$[0.100]$} \\
\hline \multirow[t]{2}{*}{ Working Age } & $1.072^{* * *}$ & 0.024 & $1.096^{* * *}$ & $1.185^{* * *}$ & 0.029 & $1.213^{* * *}$ \\
\hline & [0.362] & {$[0.030]$} & [0.371] & [0.367] & {$[0.036]$} & [0.379] \\
\hline \multirow[t]{2}{*}{ Senior } & $1.154^{* * *}$ & 0.027 & $1.182^{* * *}$ & $1.161 * * *$ & 0.029 & $1.191^{* * *}$ \\
\hline & [0.399] & [0.034] & [0.414] & [0.369] & {$[0.036]$} & [0.386] \\
\hline \multirow[t]{2}{*}{ Male } & $-1.042^{* *}$ & -0.022 & $-1.064^{* *}$ & $-1.231^{* * *}$ & -0.028 & $-1.259 * * *$ \\
\hline & [0.408] & [0.029] & [0.413] & [0.442] & {$[0.036]$} & [0.449] \\
\hline \multirow[t]{2}{*}{ White } & -0.148 & -0.003 & -0.151 & -0.204 & -0.005 & -0.209 \\
\hline & {$[0.200]$} & {$[0.007]$} & {$[0.204]$} & [0.195] & {$[0.008]$} & [0.199] \\
\hline \multirow[t]{2}{*}{ Greater Tax } & -0.005 & 0 & -0.005 & -0.005 & 0 & -0.005 \\
\hline & {$[0.004]$} & {$[0.000]$} & {$[0.004]$} & {$[0.004]$} & {$[0.000]$} & {$[0.004]$} \\
\hline \multirow[t]{2}{*}{ Lower Tax } & 0.004 & 0 & 0.004 & 0.004 & 0 & 0.004 \\
\hline & {$[0.004]$} & {$[0.000]$} & {$[0.004]$} & {$[0.004]$} & {$[0.000]$} & {$[0.004]$} \\
\hline \multirow[t]{2}{*}{ Spatial Effect } & 0.022 & 0.022 & 0.022 & 0.024 & 0.024 & 0.024 \\
\hline & {$[0.023]$} & {$[0.023]$} & {$[0.023]$} & {$[0.024]$} & {$[0.024]$} & {$[0.024]$} \\
\hline Fixed Effects & \multicolumn{3}{|c|}{ County } & \multicolumn{3}{|c|}{ County } \\
\hline Year Dummies & \multicolumn{3}{|c|}{ Yes } & \multicolumn{3}{|c|}{ Yes } \\
\hline \multicolumn{5}{|l|}{ Only Sales Tax } & \multicolumn{2}{|l|}{ Yes } \\
\hline $\mathbf{R}^{2}$ & \multicolumn{3}{|c|}{0.1549} & \multicolumn{3}{|c|}{0.1012} \\
\hline Observations & \multicolumn{3}{|c|}{19242} & \multicolumn{3}{|c|}{18171} \\
\hline
\end{tabular}

Robust standard errors in brackets

* significant at $10 \% ; * *$ significant at $5 \%$; ** significant at $1 \%$ 
Figure 1: State vs. County Annual Sales Tax Rates (2002-2011)

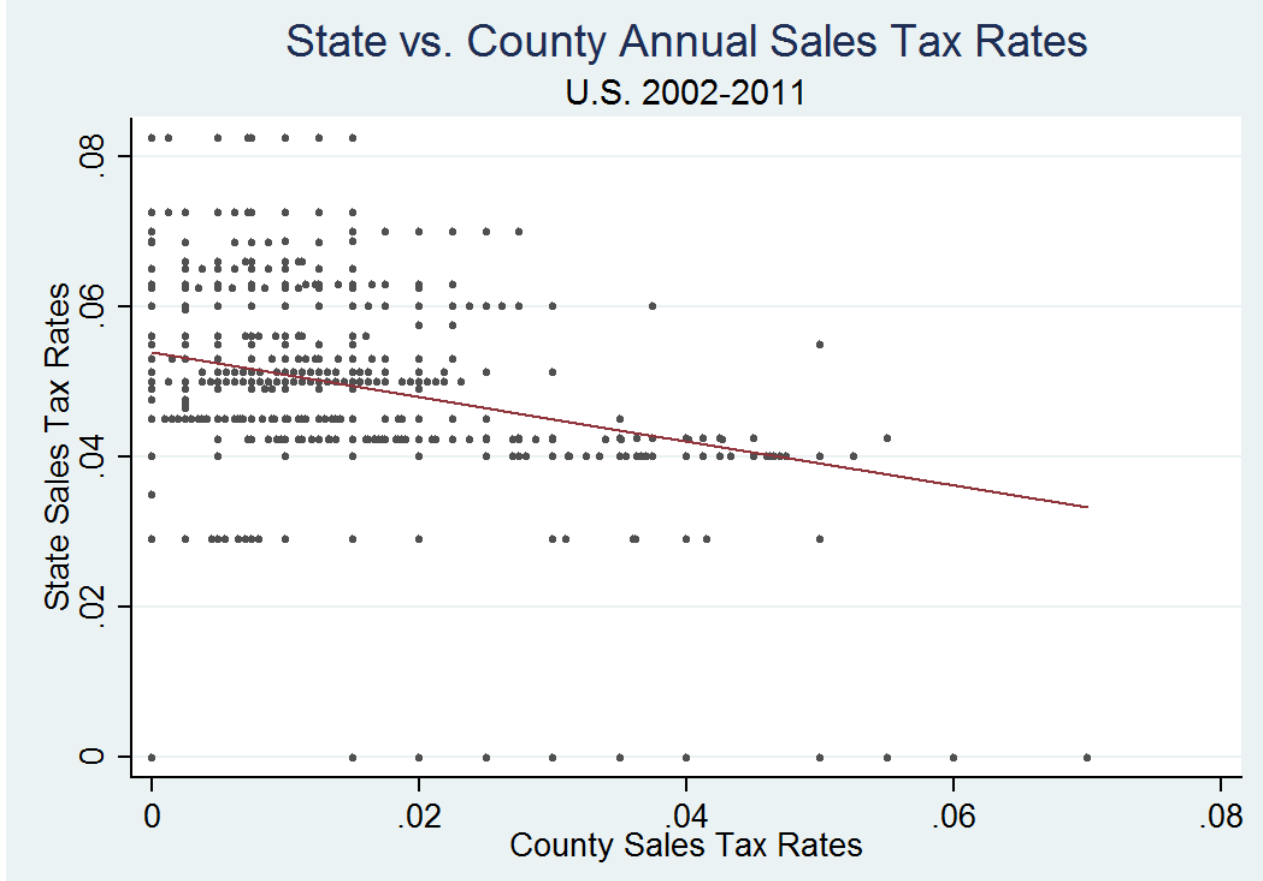

Figure 2: (Average) County Sales Tax Rate (2002-2011)

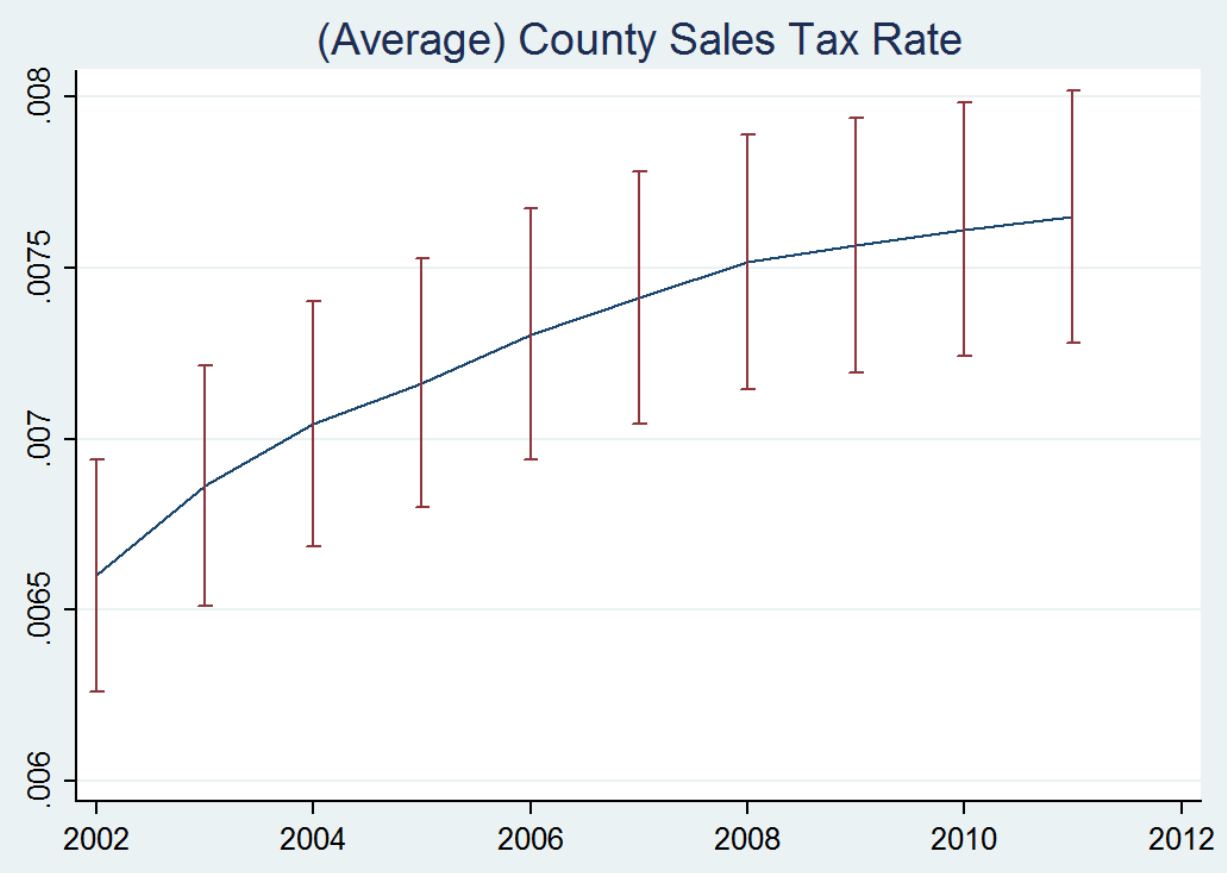


Figure 3: (Average) State Sales Tax Rate (2002-2011)

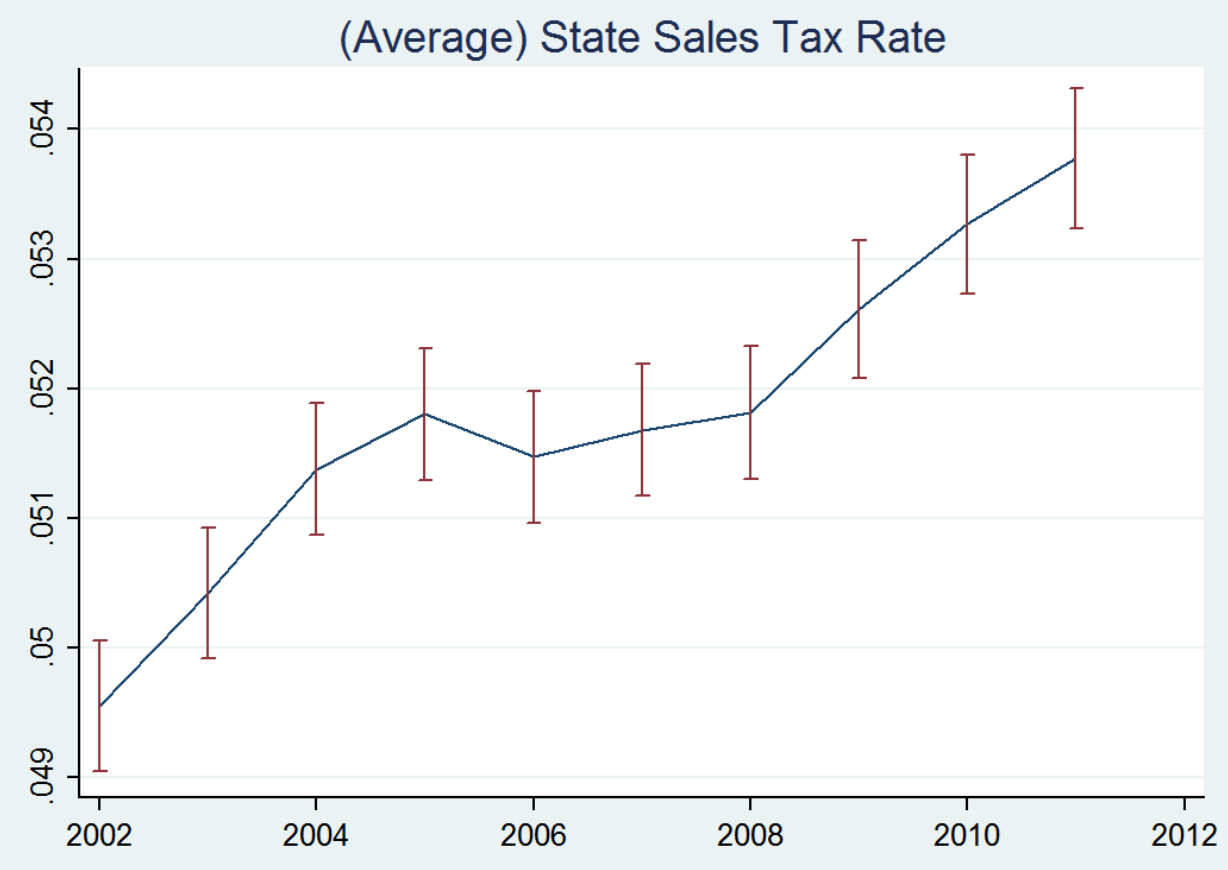

Figure 4: (Average) Combined State \& County Sales Tax Rate (2002-2011)

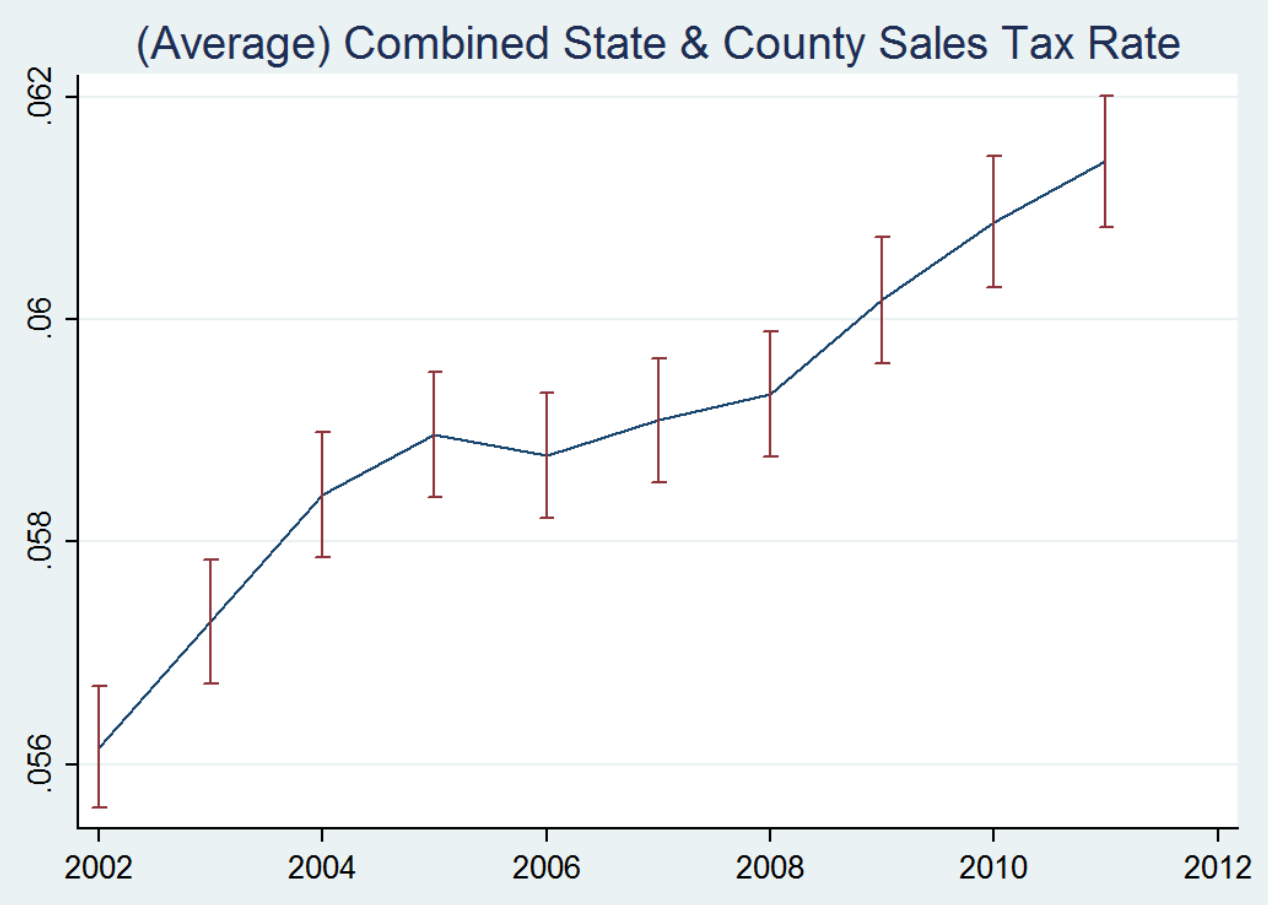


Figure 5: U.S. County Map of Combined State \& County Sales Tax Rates (2002)

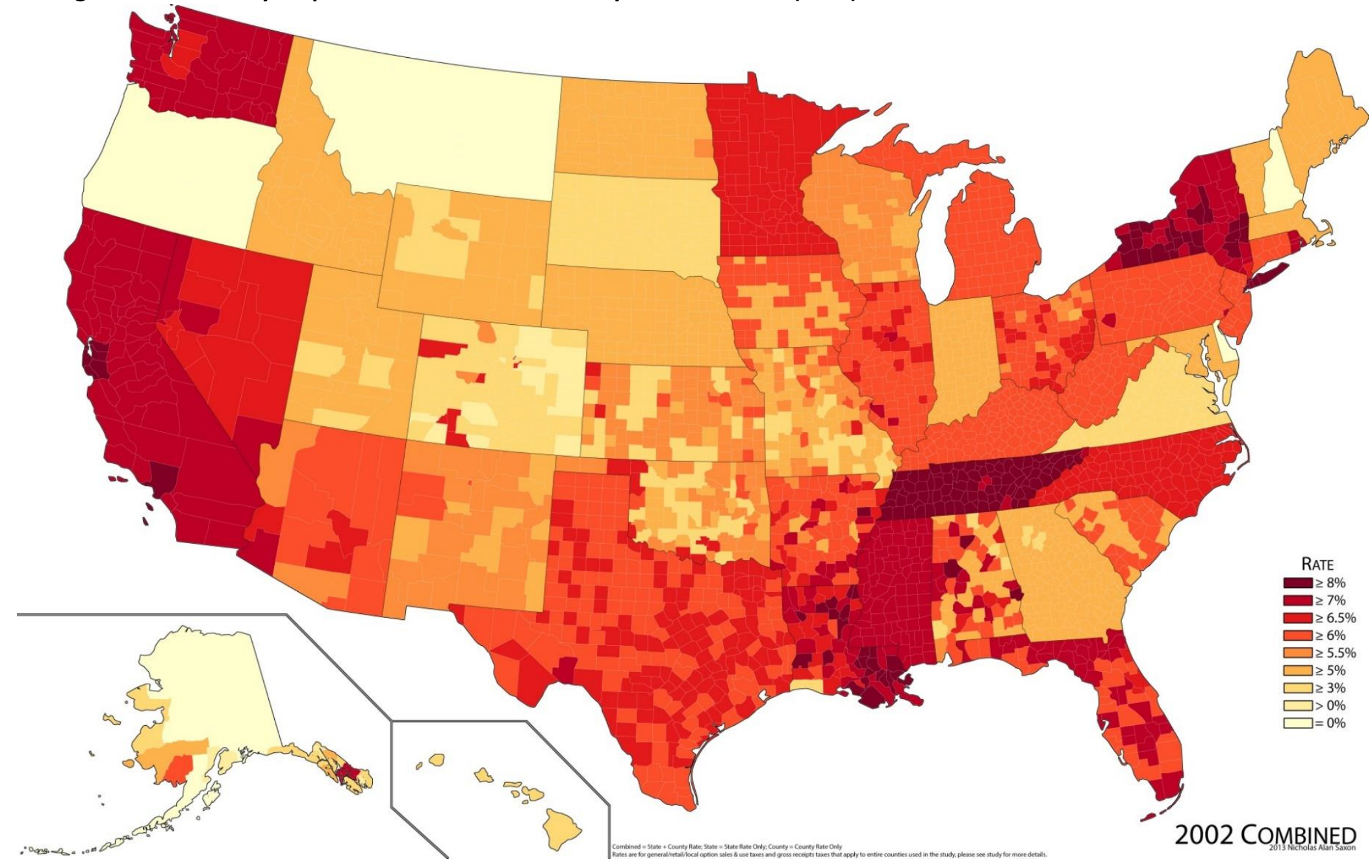


Figure 6: U.S. County Map of Combined State \& County Sales Tax Rates (2011)

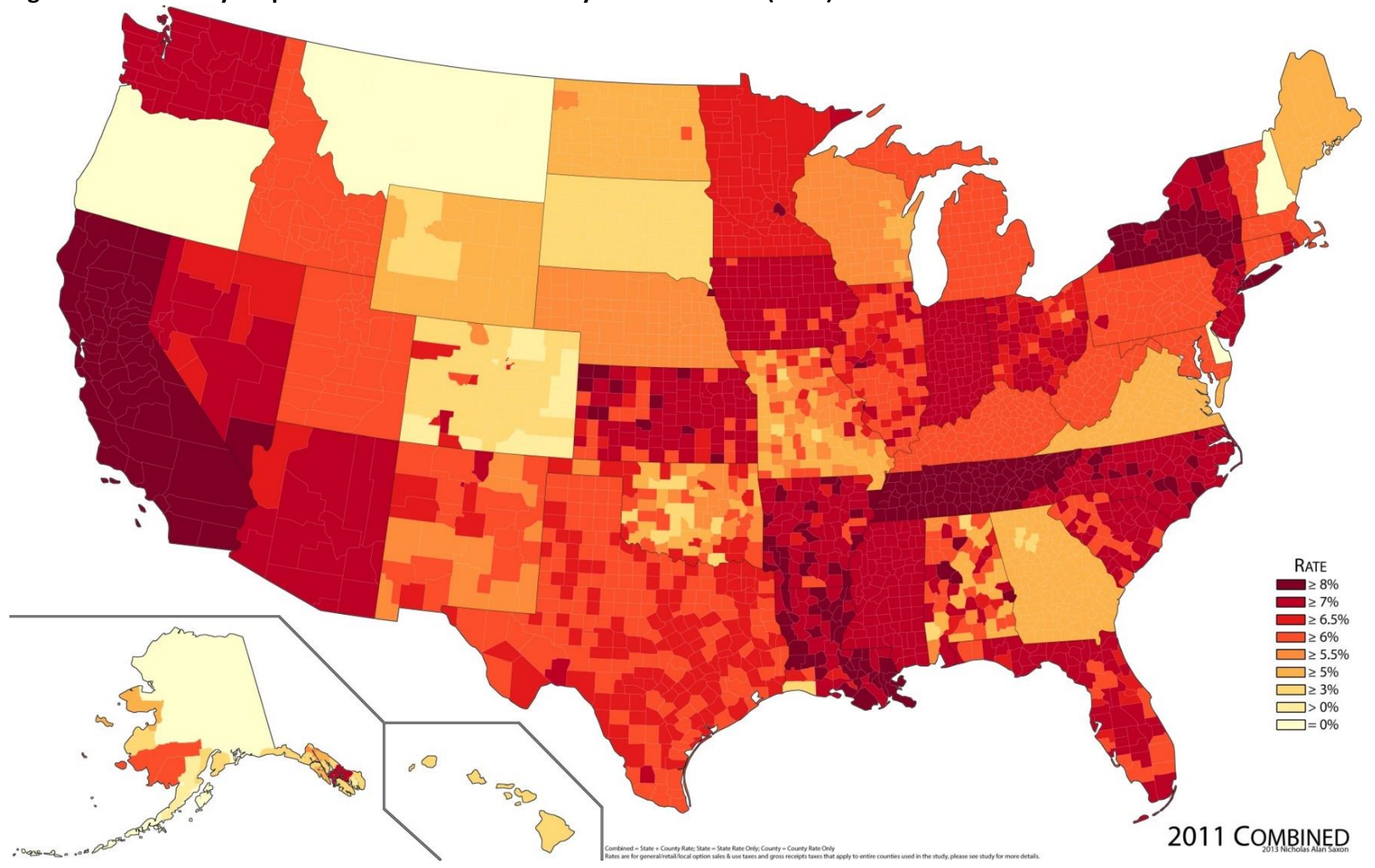

